\title{
Multiple geochemical factors may cause iodine and selenium deficiency in Gilgit-Baltistan, Pakistan
}

\author{
Saeed Ahmad • Elizabeth H. Bailey • Muhammad Arshad • Sher Ahmed • \\ Michael J. Watts $\cdot$ Scott D. Young
}

Received: 27 September 2020/Accepted: 12 April 2021 / Published online: 24 April 2021

(C) The Author(s) 2021

\begin{abstract}
Deficiencies of the micronutrients iodine and selenium are particularly prevalent where populations consume local agricultural produce grown on soils with low iodine and selenium availability. This study focussed on such an area, Gilgit-Baltistan in Pakistan, through a geochemical survey of iodine and selenium fractionation and speciation in irrigation water and arable soil. Iodine and selenium concentrations in water ranged from $0.01-1.79 \mu \mathrm{g} \mathrm{L}^{-1}$ to 0.016-2.09 $\mu \mathrm{g} \mathrm{L}^{-1}$, respectively, which are smaller than levels reported in similar mountainous areas in other parts of the world. Iodate and selenate were the dominant inorganic species in all water samples. Average concentrations of iodine and selenium in soil
\end{abstract}

Supplementary Information The online version contains supplementary material available at https://doi.org/10.1007/ s10653-021-00936-9.

S. Ahmad · E. H. Bailey $(\bowtie) \cdot$ S. D. Young Division of Agricultural and Environmental Sciences, School of Biosciences, University of Nottingham, Sutton Bonington Campus, Loughborough LE12 5RD,

Leicestershire, UK

e-mail: liz.bailey@nottingham.ac.uk

M. Arshad - S. Ahmed

Mountain Agriculture Research Centre Gilgit, Pakistan

Agricultural Research Council), Gilgit-Baltistan, Pakistan

\section{J. Watts}

Centre for Environmental Geochemistry, Inorganic

Geochemistry, British Geological Survey,

Nottingham NG12 5GG, UK were $685 \mu \mathrm{g} \mathrm{kg}^{-1}$ and $209 \mu \mathrm{g} \mathrm{kg}^{-1}$, respectively, much lower than global averages of 2600 and $400 \mu \mathrm{g} \mathrm{kg}^{-1}$, respectively. The 'reactive' fractions ('soluble' and 'adsorbed') of iodine and selenium accounted for $<7 \%$ and $<5 \%$ of their total concentrations in soil. More than $90 \%$ of reactive iodine was organic; iodide was the main inorganic species. By contrast, 66.9 and $39.7 \%$ of 'soluble' and 'adsorbed' selenium, respectively, were present as organic species; inorganic selenium was mainly selenite. Very low distribution coefficients $(\mathrm{kd}=$ adsorbed/soluble; $\mathrm{L} \mathrm{kg}^{-1}$ ) for iodine (1.07) and selenium (1.27) suggested minimal buffering of available iodine and selenium against leaching losses and plant uptake. These geochemical characteristics suggest low availability of iodine and selenium in Gilgit-Baltistan, which may be reflected in locally grown crops. However, further investigation is required to ascertain the status of iodine and selenium in the GilgitBaltistan food supply and population.

Keywords Iodine $\cdot$ Selenium $\cdot$ Soil $\cdot$ Water $\cdot$ ICPMS

\section{Background}

Iodine (I) concentration in the environment is highly variable (Wu et al., 2013). Unlike most other elements, weathering of rocks and sediments is not a major 
source of I for the soil-plant system (Johnson, 2003). Only a small proportion of the soil I available to plants is derived directly from rock weathering (Fuge \& Johnson, 2015; Jensen et al., 2019). In contrast, oceans are major reservoirs of I (Fuge \& Johnson, 2015; Manousou et al., 2019; Medrano-Macías et al., 2016) and volatilisation from ocean water and movement through the atmosphere plays an essential role in I cycling through the environment and the biosphere (Johnson, 2003; Medrano-Macías et al., 2016). Thus, I input from the atmosphere, as dry or wet precipitation, often contributes greatly to soil and plant I (Bowley et al., 2019; Fuge \& Johnson, 1986; Jensen et al., 2019; Johnson, 2003). It is recognised that I concentrations are greater in coastal areas compared to inland and mountainous regions located away from coasts (Bowley et al., 2016; Fuge \& Johnson, 2015; Humphrey et al., 2018). Apart from inputs, the concentration of I in soil is also affected by several factors affecting the retention capacity of the soil; these include climate, topography and soil characteristics such as organic matter concentration and pH (Bowley et al., 2019; Fuge \& Johnson, 2015; Humphrey et al., 2018, 2020; Mohiuddin et al., 2019). Therefore, a soil with a large I concentration does not necessarily produce I-rich plants because of factors affecting the availability of soil I (Bowley et al., 2019; Fuge \& Johnson, 1986; Mohiuddin et al., 2019). Fresh waters generally have low I concentrations (Fuge \& Johnson, 2015; Johnson, 2003) unless rivers run through I-rich sedimentary rocks (Fuge, 1989; Moran et al., 2002), whereas groundwaters typically have higher I concentrations; values of up to $1890 \mu \mathrm{g} \mathrm{L}^{-1}$ have been reported in some areas (Li et al., 2013; Qian et al., 2017). Iodine is not considered essential for terrestrial plants; however, plants absorb I through their roots and leaves (Bowley et al., 2019; Medrano-Macías et al., 2016). The rate of I accumulation differs between plants (Hong et al., 2007; Whitehead, 1984). For example, Hong et al., (2007) in their study on I accumulation in various vegetables reported that I accumulation rate varied in vegetables in the order: pakchoi $>$ celery $>$ radish $>$ capsicum.

Selenium (Se) is among the most widely distributed elements in the Earth's crust and is mainly associated with sulphide minerals (Dhillon et al., 2019; Johnson et al., 2010; Wang et al., 2016). Weathering of rocks is one of the primary sources of $\mathrm{Se}$ in soil (Fordyce, 2013; Saha et al., 2017; Shamberger, 1981). The majority of rocks contain low concentrations of Se; therefore, Se-deficient soils are more common than 'seleniferous' soils (Fordyce, 2013). Selenium concentration in most soils ranges from 0.01 to $2.0 \mathrm{mg} \mathrm{kg}^{-1}$ although some seleniferous soils have Se concentration up to $1250 \mathrm{mg} \mathrm{kg}^{-1}$ (Dhillon et al., 2019; Fordyce, 2013; Fordyce et al., 2010; Winkel et al., 2012). Most surface waters have small concentrations of Se $\left(0.06-0.12 \mu \mathrm{g} \mathrm{L}^{-1}\right)$, whereas groundwater Se can reach up to $6000 \mu \mathrm{g} \mathrm{L}^{-1}$ in some areas (Alexander, 2015; Fordyce, 2013), presumably because of Se-rich parent material. Selenium is not considered essential for higher plants, but it is taken up by plants via sulphate (selenate) and phosphate (selenite) transporters (Alexander, 2015; Gupta \& Gupta, 2017; Malagoli et al., 2015; Riaz et al., 2018; White, 2016). Plants differ in their ability to accumulate Se (Alexander, 2015; Broadley et al., 2006; Barillas et al., 2011; Ebrahimi et al. 2019; Woch \& Hawrylak-Nowak, 2019; Yang et al. 2017). For example, Brassica species (rapeseed, broccoli, cabbage), allium spices (onion and garlic) and Brazil nuts accumulate higher concentration of Se compared to grasses and grains (wheat, oats, rye and barley) (Alexander, 2015; Yang et al., 2017).

Both I and Se are important micronutrients for human and animal health, and their deficiency or toxicity can result in serious health complications. Deficiencies can be resolved by supplying sufficient I and $\mathrm{Se}$ in the diets of affected populations via food fortification with I and Se or use of iodised salt (Hetzel, 1983; Lyons, 2018; Malagoli et al., 2015; Rayman, 2000; Sun et al., 2017;). Iodine deficiency is generally widespread in remote mountainous areas (Faridullah, 2017; Kelly \& Snedden, 1958). Thus, Gilgit-Baltistan, located in the Himalayan region, has a history of I deficiency disorders (IDD) (Stewart, 1990; Shah et al., 2014; Faridullah et al., 2017; Khattak et al., 2017). Furthermore, co-existing deficiency of I and Se can result in some extreme forms of IDD (e.g. cretinism) (Eastman \& Zimmermann, 2018; Lyons, 2018; Vanderpas et al., 1990); incidence of cretinism has been historically reported in GilgitBaltistan (Stewart, 1990). The population of GilgitBaltistan largely consume locally grown agricultural produce (Mountain Agriculture Research Centre, personal communication, December 2019), and there is limited data available on the status of environmental I and Se in Gilgit-Baltistan. 
This study aimed to assess the status of I and Se in Gilgit-Baltistan, focussing on factors controlling I and Se concentration and speciation in soils and water and their potential availability to plants.

\section{Methods}

Study sites

Study sites were selected in five districts of GilgitBaltistan, which were chosen based on their accessibility and the availability of fertile agriculture land; the sites were identified with the help of colleagues from the Mountain Agriculture Research Centre (MARC). The sampling districts included Gilgit, Diamer, Hunza-Nagar (Hunza-N), Astor and Skardu (Fig. 1). Overall, twenty-six villages were surveyed with five villages from each district apart from Hunza$\mathrm{N}$ where six villages were sampled. At the time of planning this project, Hunza-N was one district, but it was later divided into district Hunza and district Nagar; in this study, we have referred to Hunza-N as one district. All the sampling sites were located within the altitude range 1000 to $2700 \mathrm{~m}$ above sea level and approximately $1400 \mathrm{~km}$ from the nearest coast.

Sample collection and processing

Samples were collected in July and August of 2016. Water was sampled in the villages identified for soil sampling and also between sample villages. A total of 66 irrigation water samples were collected from surface water sources including rivers, streams and lakes. Water samples were filtered at the point of sampling, using syringe filters $(<0.22 \mu \mathrm{m})$ and kept in the dark during transportation to the MARC laboratory in Gilgit where they were stored at $4{ }^{\circ} \mathrm{C}$ pending shipping to the University of Nottingham for elemental analysis by ICP-MS.

A composite topsoil $(0-20 \mathrm{~cm})$ sample was collected with a stainless-steel auger from arable land in each village. The soil was air-dried and sieved $(<2 \mathrm{~mm})$ at the MARC laboratory and then shipped to the University of Nottingham where a sub-sample of $10 \mathrm{~g}$ was finely ground in an agate ball mill (Retsch PM400, Haan, Germany) for elemental analysis.
Sample characterisation and chemical analysis

\section{Water}

Water $\mathrm{pH}$ and electric conductivity (EC) were measured with a portable $\mathrm{pH}$ and EC meter (HANNA HI98129) at the source. Dissolved inorganic carbon (DIC) and total carbon (TC) in water samples were measured on a Shimadzu TOC-VCPH coupled with an ASI-V unit (Shimadzu UK Ltd) after diluting the water sample $(10 \mathrm{~mL}$ sample $+10 \mathrm{~mL}$ Milli-Q water (18.2 $\mathrm{M} \Omega \mathrm{cm})$ ) following Karim (2018). A range of concentrations (10 to $50 \mathrm{mg} \mathrm{L} \mathrm{L}^{-1}$ ) of potassium hydrogen phthalate $\left(\mathrm{C}_{8} \mathrm{H}_{5} \mathrm{KO}_{4}\right)$ were used to calibrate the instrument for TC analysis, while $\mathrm{Na}_{2} \mathrm{CO}_{3}$ (10-50 mg L ${ }^{-1}$ ) was used for DIC calibration. Dissolved organic carbon (DOC) was determined by difference (TC - DIC). Selenium and I analysis were undertaken using a single quadrupole ICP-MS (model iCAP-Q, Thermo Scientific, Bremen, Germany) on samples preserved in $2 \% \mathrm{HNO}_{3}$ and $1 \%$ tetra methyl ammonium hydroxide (TMAH), respectively.

\section{Soil}

Soil $\mathrm{pH}$ was measured using a $\mathrm{pH}$ meter (HANNA, model $\mathrm{pH} 209$ ) with combined glass electrode on a soil-water suspension of $5 \mathrm{~g}$ soil $(<2 \mathrm{~mm}$ sieved) and $12.5 \mathrm{~mL}$ Milli-Q water after shaking on an end-overend shaker for $30 \mathrm{~min}$ (Rowell, 1994). Mechanical analysis (soil texture) was undertaken by laser granulometry to determine clay $(<4 \mu \mathrm{m})$, silt $(\geq 4 \mu \mathrm{m}$ and $\leq 63 \mu \mathrm{m})$ and sand $(>63 \mu \mathrm{m})$ particles; the grain size $<4 \mu \mathrm{m}$ was used to define clay particles following Kerry et al., (2009). The finely ground soil was used for measuring concentrations of total carbon and inorganic carbon in an Elemental Analyser (Model Flash EA1112, CE Instruments) and Shimadzu TOCVCPH coupled with an SSM-5000A solids module (Shimadzu UK Ltd), respectively, following Mathers (2015) and Ligowe et al., (2019).

Oxides of $\mathrm{Fe}, \mathrm{Mn}$ and $\mathrm{Al}$ in soil samples were determined in citrate-bicarbonate-dithionate (CBD) extracts of finely ground soil by ICP-MS following Mathers (2015) and Ligowe et al., (2019). Soil total I $\left(\mathrm{I}_{\mathrm{T}}\right)$ was extracted with $10 \%$ TMAH which was diluted to $1 \%$, after centrifugation (2500 g), for analysis by ICP-MS as described in Watts and Mitchell (2009). Acid digestion $\left(\mathrm{HNO}_{3}-\mathrm{HClO}_{4}-\mathrm{HF}\right)$ of finely ground 


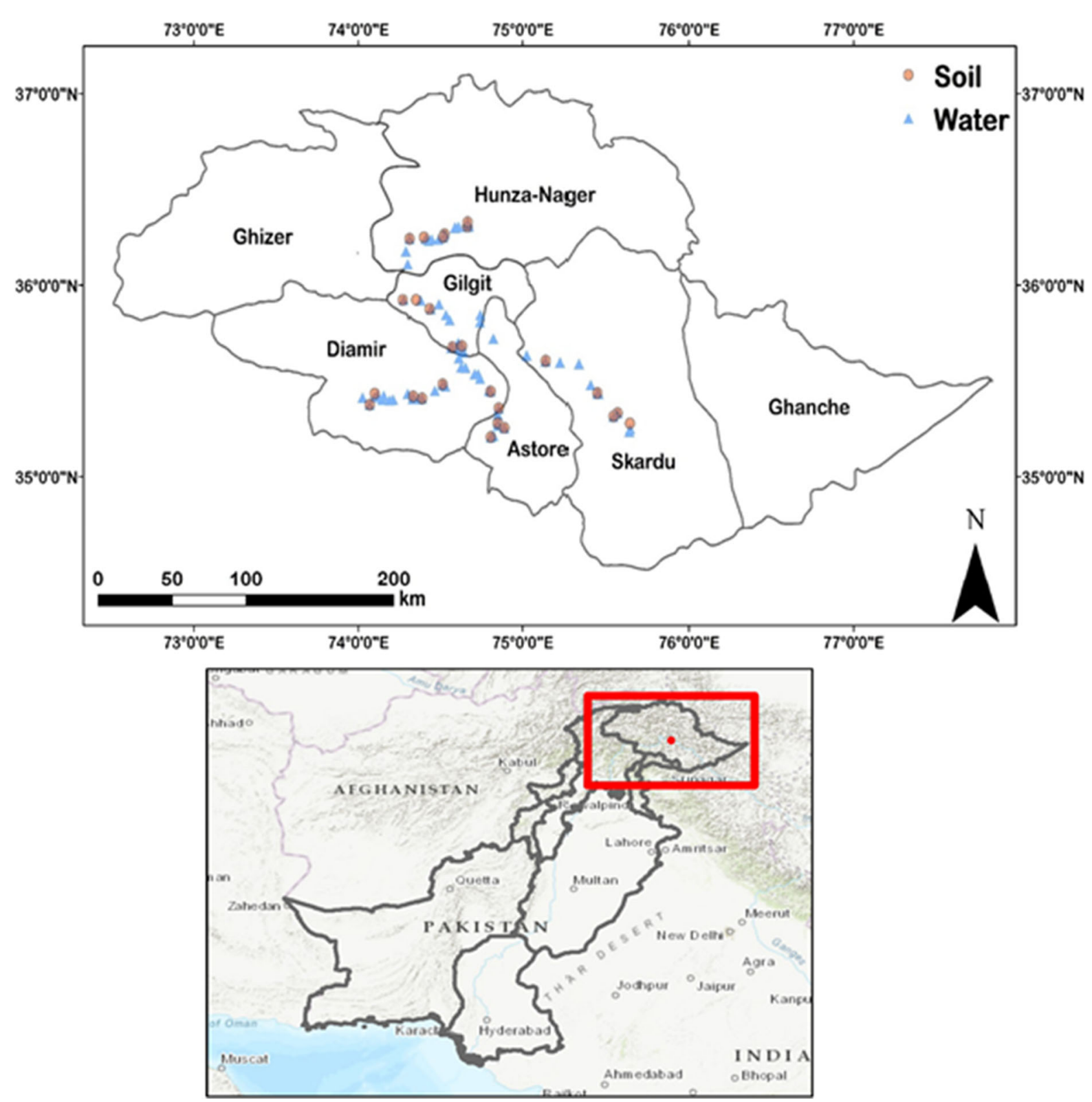

Fig. 1 Sampling locations in Gilgit-Baltistan

soil was undertaken in PFA vessels using a tefloncoated graphite block digester (Model A3, Analysco Ltd) controlled by a Eurotherm temperature control unit following Mathers (2015), Karim (2018) and Sanders (2018). Soil digests were diluted in Milli-Q water prior to analysis of total selenium $\left(\mathrm{Se}_{\mathrm{T}}\right)$ concentration by ICP-MS.

A three-stage sequential extraction of $<2 \mathrm{~mm}$ sieved soil was undertaken with potassium nitrate $\left(0.01 \mathrm{M} \mathrm{KNO}_{3}\right)$ followed by potassium dihydrogen phosphate $\left(0.016 \mathrm{M} \mathrm{KH}_{2} \mathrm{PO}_{4}\right)$ to determine 'soluble' and 'adsorbed' fractions of I and Se following Karim (2018) and Ligowe et al., (2020). This was followed by extraction with $10 \%$ TMAH to determine 'Organic' fractions of Se and I. Speciation analysis of I and Se were undertaken on the $\mathrm{KNO}_{3}$ and $\mathrm{KH}_{2} \mathrm{PO}_{4}$ extracts of soil samples using an HPLC unit (Dionex ISC-5000) coupled to the ICP-MS as mentioned in Bowley et al., (2016), Karim (2018) and Sanders (2018). The chromatography eluent consisted of $4.00 \mathrm{~g} \mathrm{~L}^{-1}$ 
$\mathrm{NH}_{4} \mathrm{NO}_{3}, 20 \mathrm{mLl} \mathrm{L}^{-1}$ methanol, $0.00325 \mathrm{~g} \mathrm{~L}^{-1} \mathrm{NH}_{4}$ EDTA and $12.1 \mathrm{~g} \mathrm{~L}^{-1}$ Tris buffer. The stationary phase used was a Hamilton PRP X-100 anion exchange column $(100 \times 4.1 \mathrm{~mm} ; 5 \mu \mathrm{m}$ particle size); the eluent flow rate was $1.4 \mathrm{~mL} \mathrm{~min}^{-1}$. Working standards of $5 \mu \mathrm{g} \mathrm{L}^{-1} \mathrm{I}$ and Se reduced species ( $\mathrm{I}^{-}$ and $\left.\mathrm{Se}^{\mathrm{IV}}\right)$ and oxidised species $\left(\mathrm{IO}_{3}{ }^{-}\right.$and $\left.\mathrm{Se}^{\mathrm{VI}}\right)$ were run between the samples at regular intervals to enable correction for instrumental drift. The peaks obtained for each sample were manually integrated using Chromeleon $^{\mathrm{TM}}$ software, and then, peak areas were converted to concentration in Microsoft Excel 2016 by considering the peak area of standards (supplementary information Figs A1 and A2) as reference. Species determined included iodide, iodate, selenite and selenate; organic I and Se species were calculated by difference from the total I and Se concentrations in the 'soluble' and 'adsorbed' fractions.

Distribution coefficient of iodine and selenium in soil

The distribution coefficient $(\mathrm{kd})$ is the ratio of adsorbed fraction to soluble fraction and was calculated both for I and Se, respectively, from Eq. 1.
Fig. 2 Principal component analysis results of iodine and selenium in soil a location of soil samples, b parameters affecting iodine and selenium concentration in soil

$\mathrm{kd}=\frac{C_{\mathrm{ads}}}{C_{\mathrm{sol}}}$

where $\mathrm{C}_{\mathrm{ads}}$ and $\mathrm{C}_{\mathrm{sol}}$ are the concentrations of soil I or $\mathrm{Se}\left(\mu \mathrm{g} \mathrm{kg}^{-1}\right)$ in the adsorbed and soluble fractions.

Quality control and quality assurance

All sample preparation and analysis procedures were undertaken with replication; generally, replicates were within $\pm 1 \%$ for individual samples. Operational blanks (OBs) were run within each batch of analysis to correct for contamination associated with the sample preparation and analytical procedures. The OBs were also used to estimate limits of detection $(3 \times$ standard deviation of $10 \times \mathrm{OBs})$. A soil certified reference material (CRM) (Montana soil - NIST 2711a) was used for quality assurance of the elemental analysis. The average recovery of Se in the CRM was within $\pm 10 \%$ of the reported values. Calibration solutions of I and Se were always run prior to and during sample analysis by ICP-MS; internal standards were used to correct for drift ( $\mathrm{Rh}$ in acidic matrices, $\mathrm{Re}$ in TMAH).

\section{Statistical analysis}

Basic statistical calculations including mean, median, standard error and standard deviation were performed in Microsoft Excel 2016. Pearson's correlation analysis, analysis of variance (ANOVA) and principal component analysis (PCA) were performed in Minitab (version 18.1). Pearson's correlation was used to describe association between analytes and various characteristics of water and soil samples, while ANOVA was applied to determine whether there was any significant difference between data from different locations. A $p$ value of $<0.05$ was considered significant.

\section{Results and discussion}

Water characteristics

The basic characteristics of all water samples are provided in supplementary information (Table B1). The majority of water characteristics, with the exception of $\mathrm{pH}$, did not show significant variation among districts $(p>0.05)$. The median $\mathrm{pH}$ of samples was 7.9 and ranged from 7.0 to 9.2. Water EC was less than $1.0 \mathrm{dS} \mathrm{m} \mathrm{m}^{-1}$ in all samples with mean and median values of 0.210 and $0.173 \mathrm{dS} \mathrm{m}^{-1}$, respectively. Water with $\mathrm{EC}<0.75 \mathrm{dS} \mathrm{m}^{-1}$ is suitable for irrigation and does not have any detrimental effect on plant growth (Bortolini et al., 2018; Zaman et al., 2018). Dissolved inorganic carbon (DIC) accounted for a large proportion $(>85 \%)$ of total carbon compared to dissolved organic carbon (DOC). Median DIC and DOC concentrations were 10.5 and $1.38 \mathrm{mg} \mathrm{L}^{-1}$, respectively, in all samples. The hardness of water, calculated as the apparent concentration of $\mathrm{CaCO}_{3}$, ranged from $21.1 \mathrm{mg} \mathrm{L}^{-1}$ to $328 \mathrm{mg} \mathrm{L}^{-1}$ in all water samples; concentrations of $\mathrm{CaCO}_{3} \leq 60 \mathrm{mg} \mathrm{L}^{-1}, 61-120 \mathrm{mg}$ $\mathrm{L}^{-1}, 121-180 \mathrm{mg} \mathrm{L}^{-1}$ and more than $180 \mathrm{mg} \mathrm{L}^{-1}$ are categorised as soft, moderately hard, hard and very hard, respectively (McGowan, 2000; USGS 2021). The sodium adsorption ratio (SAR) in all water samples was $<1$ which means there is unlikely to be a problem with soil sodicity; values of $\mathrm{SAR}<3$ are suitable for a wide range of crops and unlikely to cause any soil health problems (Bortolini et al., 2018).

Iodine in water

\section{Total iodine}

Iodine concentration in all water samples $(n=66)$ ranged from 0.01 to $1.79 \mu \mathrm{g} \mathrm{L}^{-1}$ with a median of $0.20 \mu \mathrm{g} \mathrm{L}^{-1}$ (supplementary information Table B1). There was no significant difference in I concentration between districts $(p>0.05)$. The I concentrations observed in the current study are at the lower end of the global surface water concentration range (0.01-212 $\mu \mathrm{g} \mathrm{L}^{-1}$ ) reported by Fuge and Johnson (2015). Values of I were also less than I concentration in water from other regions with similar mountainous topography, such as Kabul and Nangarhar Afghanistan with average values of 15.4 and $7.6 \mu \mathrm{g} \mathrm{L}^{-1}$, respectively (Watts \& Mitchell, 2009); San Juan province in Argentina at an average $40.2 \mu \mathrm{g} \mathrm{L}^{-1}$ (Watts, 2010); Kilimajaro district in Tanzania with an average I concentration of $22.4 \mu \mathrm{g} \mathrm{L}^{-1}$ (Watts et al., 2019). However, the results for Gilgit-Baltistan are comparable with I concentrations $\left(<0.1 \mu \mathrm{g} \mathrm{L}^{-1}\right)$ reported by Day and Powell-Jackson (1972) in the Himalayan region of Nepal. Multiple factors, such as distance from the sea, rainfall and underlying geology, affect I 
concentration in fresh water (Fuge \& Johnson, 2015). The nearest coast to the study area is at a distance of about $1400 \mathrm{~km}$ which reduces the chances of any marine influence in water I recharge. Furthermore, the area is located within a rain shadow and hence receives rainfall of only $254 \mathrm{~mm}$ per year. The geology is igneous or metamorphic in nature and highly variable (Malik \& Azam, 2009). The low precipitation rates and the presence of igneous/metamorphic rocks are contributing factors to the low I concentrations in waters of the study area.

\section{Speciation of iodine in water}

Iodine was present both in inorganic and organic forms in all samples, but the species composition did not follow any obvious trend with location. However, inorganic species typically accounted for a larger percentage (mean $=69 \%$ ) of total I in the majority of samples. This is comparable with data reported by Karim (2018) who measured I speciation in irrigation waters from Sulaimani province of Iraqi Kurdistan and found a higher proportion of inorganic species. A correlation (Pearson $r=0.490, p<0.001$ ) between DIC and inorganic I was observed which may reflect local geology. The smaller proportion of organic I (mean $=31 \%)$ may reflect the low concentration of DOC in water samples. The ratio of DOC $\left(\mathrm{mg} \mathrm{L}^{-1}\right)$ to organic I $\left(\mu \mathrm{g} \mathrm{L}^{-1}\right)\left(\mathrm{DOC} / \mathrm{I}_{\mathrm{org}}\right)$ was variable (range: 0.00-23,200, median: 21.4) across samples and did not show any significant trend with location.

Inorganic I in water samples was predominantly present as iodate $\left(\mathrm{IO}_{3}{ }^{-}\right)$, possibly reflecting the alkaline conditions as nearly all samples had $\mathrm{pH}$ values above 7. Moran et al., (2002) reported that $\mathrm{IO}_{3}{ }^{-}$ is typically the predominant inorganic I species under alkaline conditions in water and soil. Our data are comparable with the findings reported by Gilfedder et al., (2009), Hansen (2011) and Karim (2018) that inorganic $\mathrm{I}$ is largely present as $\mathrm{IO}_{3}{ }^{-}$in natural water. However, iodide $\left(\mathrm{I}^{-}\right)$dominated in a subset of samples potentially a consequence of its presence in this form in rocks and soil of the watershed. Smith and Butler (1979) reported that high concentrations of $\mathrm{I}^{-}$in the Yarra river in Autralia were probably because of the dominant presence of $\mathrm{I}^{-}$in soils and rocks in the river Yarra drainage basin, assuming no conversion of inorganic I species occurred in transit. An alternative reason for $\mathrm{I}^{-}$enrichment in water may be the reduction in $\mathrm{IO}_{3}{ }^{-}$to $\mathrm{I}^{-}$due to microbial activity under reducing conditions (Li, Qian, et al., 2017).

Selenium in water

\section{Total selenium}

Selenium in water samples ranged from 0.016 to $2.09 \mu \mathrm{g} \mathrm{L}^{-1}$ with a median concentration of $0.161 \mu \mathrm{g}$ $\mathrm{L}^{-1}$ (supplementary information Table B1). A significant difference was observed in Se concentration between districts $(p<0.05)$. The results of this study are in agreement with other investigations. Wang et al., (1994) reported that the Se concentrations in river waters of several European countries, Japan and USA are largely $<1 \mu \mathrm{g} \mathrm{L}^{-1}$. Selenium concentrations in fresh water generally fall within the range $0.1-100 \mu \mathrm{g} \mathrm{L}^{-1}$ with most of the values below $3 \mu \mathrm{g}$ $\mathrm{L}^{-1}$ (Fordyce, 2007, 2013). Watts and Mitchell (2009) reported an average concentration of $1.84 \mu \mathrm{g} \mathrm{L}^{-1} \mathrm{Se}$ in surface water from a similar hilly area in Argentina. The low concentration of $\mathrm{Se}$ in the current study probably reflects the igneous and metamorphic geology of the area which is very low in Se. There was no correlation between concentration of Se, or individual Se species, and most water characteristics, such as $\mathrm{pH}$ and DOC $(p>0.05)$. However, Se concentration had a significant correlation $(r=0.549, p<0.01)$ with DIC in water samples which may either reflect a calcareous origin for the $\mathrm{Se}$ or its $\mathrm{pH}$-dependent solubility.

\section{Speciation of selenium in water}

Typically, Se was present both in inorganic and organic forms in water samples. On average, inorganic species accounted for the larger proportion $(63 \%)$ of Se, while the remaining $37 \%$ was present in organic form. In all cases, the inorganic Se was present as selenate $\left(\mathrm{Se}^{\mathrm{VI}}\right)$; no selenite $\left(\mathrm{Se}^{\mathrm{IV}}\right)$ was detected in any of the water samples (supplementary information Table B1). The dominant presence of inorganic $\mathrm{Se}^{\mathrm{VI}}$ is comparable with other studies. Wang et al., (1994) reported higher concentrations of inorganic Se, with $\mathrm{Se}^{\mathrm{VI}}$ as the principal species, in river waters from Finland, Japan and USA. Other workers such as Conde and Alaejos (1997) and Cutter (1985) have also reported that $\mathrm{Se}^{\mathrm{VI}}$ was the major inorganic species in river waters from various countries. Bujdoš et al., 
Table 1 Basic characteristics of soil samples from all sampling districts (BDL: below detection limit)

\begin{tabular}{|c|c|c|c|c|c|c|c|c|c|c|c|}
\hline District & Sample code & $\mathrm{pH}$ & $\begin{array}{l}\text { SIC } \\
\%\end{array}$ & SOC & Sand & Silt & Clay & $\begin{array}{l}{ }^{1} \mathrm{Fe}-\mathrm{ox} \\
\left(\mathrm{g} \mathrm{kg}^{-1}\right)\end{array}$ & ${ }^{2}$ Mn-ox & ${ }^{3} \mathrm{Al}-\mathrm{ox}$ & ${ }^{4}$ Comb-ox \\
\hline \multirow[t]{5}{*}{ Gilgit } & G01 & 7.19 & BDL & 0.983 & 79.1 & 18.7 & 2.25 & 3.33 & 0.119 & 0.322 & 3.77 \\
\hline & G02 & 7.77 & 0.008 & 1.52 & 74.2 & 22.7 & 3.12 & 3.29 & 0.097 & 0.349 & 3.73 \\
\hline & G03 & 8.06 & 0.525 & 1.48 & 55.4 & 39.8 & 4.87 & 2.94 & 0.162 & 0.250 & 3.35 \\
\hline & G04 & 7.22 & 0.006 & 0.661 & 54.3 & 42.8 & 2.89 & 1.92 & 0.055 & 0.250 & 2.23 \\
\hline & G05 & 7.43 & 0.001 & 1.37 & 67.5 & 29.8 & 2.68 & 4.08 & 0.078 & 0.268 & 4.42 \\
\hline \multirow[t]{5}{*}{ Diamer } & D06 & 7.90 & 0.040 & 0.976 & 81.0 & 16.4 & 2.62 & 2.04 & 0.073 & 0.197 & 2.31 \\
\hline & D07 & 7.70 & BDL & 0.841 & 74.4 & 23.3 & 2.31 & 2.38 & 0.055 & 0.247 & 2.68 \\
\hline & D08 & 7.93 & 0.024 & 0.989 & 72.5 & 23.8 & 3.71 & 3.91 & 0.137 & 0.302 & 4.35 \\
\hline & D09 & 7.21 & 0.007 & 1.90 & 74.4 & 21.3 & 4.26 & 3.59 & 0.130 & 0.266 & 3.99 \\
\hline & D10 & 7.89 & 0.002 & 1.04 & 70.9 & 25.6 & 3.55 & 2.38 & 0.071 & 0.223 & 2.67 \\
\hline \multirow[t]{6}{*}{ Hunza-N } & N11 & 8.26 & 1.41 & 1.45 & 59.4 & 34.9 & 5.68 & 6.68 & 0.160 & 0.276 & 7.11 \\
\hline & H12 & 7.87 & 0.686 & 2.75 & 61.7 & 33.8 & 4.54 & 7.27 & 0.184 & 0.294 & 7.75 \\
\hline & N13 & 8.19 & 0.691 & 2.65 & 36.7 & 51.3 & 11.9 & 3.89 & 0.192 & 0.261 & 4.35 \\
\hline & H14 & 8.28 & 0.469 & 1.94 & 63.9 & 33.0 & 3.06 & 4.82 & 0.084 & 0.232 & 5.14 \\
\hline & H15 & 7.87 & 0.137 & 2.46 & 76.6 & 21.8 & 1.59 & 4.20 & 0.077 & 0.257 & 4.54 \\
\hline & N16 & 7.92 & 0.963 & 2.77 & 60.5 & 35.9 & 3.51 & 3.24 & 0.090 & 0.186 & 3.52 \\
\hline \multirow[t]{5}{*}{ Astor } & A17 & 7.34 & 0.005 & 2.03 & 72.2 & 25.2 & 2.56 & 2.04 & 0.053 & 0.167 & 2.26 \\
\hline & A18 & 6.83 & BDL & 1.57 & 74.1 & 23.0 & 2.91 & 1.92 & 0.060 & 0.242 & 2.22 \\
\hline & A19 & 6.90 & BDL & 0.410 & 82.2 & 16.3 & 1.48 & 3.23 & 0.054 & 0.220 & 3.50 \\
\hline & A20 & 7.16 & BDL & 2.21 & 74.2 & 22.2 & 3.67 & 4.48 & 0.179 & 0.453 & 5.12 \\
\hline & A21 & 6.70 & BDL & 1.62 & 74.8 & 21.9 & 3.35 & 2.79 & 0.096 & 0.370 & 3.26 \\
\hline \multirow[t]{5}{*}{ Skardu } & $\mathrm{S} 22$ & 8.18 & 0.038 & 1.11 & 58.6 & 38.1 & 3.33 & 1.97 & 0.081 & 0.192 & 2.24 \\
\hline & $\mathrm{S} 23$ & 7.51 & 0.004 & 1.99 & 69.2 & 27.8 & 2.98 & 2.51 & 0.116 & 0.307 & 2.93 \\
\hline & $\mathrm{S} 24$ & 8.04 & 1.30 & 1.42 & 39.6 & 51.3 & 9.10 & 4.42 & 0.146 & 0.258 & 4.83 \\
\hline & $\mathrm{S} 25$ & 8.33 & 1.54 & 1.06 & 57.2 & 36.7 & 6.11 & 4.12 & 0.110 & 0.216 & 4.45 \\
\hline & S26 & 8.23 & 0.448 & 0.984 & 64.5 & 31.0 & 4.53 & 2.97 & 0.137 & 0.240 & 3.34 \\
\hline
\end{tabular}

${ }^{1}$ Iron oxide, ${ }^{2}$ Manganese oxide, ${ }^{3}$ Aluminium oxide, ${ }^{4}$ Combined metal oxides of Fe, Mn and $\mathrm{Al}$

(2005) studied Se speciation in water from Slovakia which indicated $\mathrm{Se}^{\mathrm{VI}}$ as the major species in water with $\mathrm{pH}>7$. The greater concentration of $\mathrm{Se}^{\mathrm{VI}}$ may be explained by its greater solubility, and weaker adsorption on sediments, compared to $\mathrm{Se}^{\mathrm{IV}}$ (Cary \& Gissel-Nielsen, 1973; Fishbein, 1983; Wang et al., 1994; Wuilloud \& Berton, 2014) or because Se is naturally present in this form in soils and rocks of the area.

\section{Soil characteristics}

Details of basic soil characteristics including soil $\mathrm{pH}$, texture, concentrations of inorganic and organic carbon and metal oxides are given in Table 1. Soils fell in the $\mathrm{pH}$ range of 6.70 to 8.33 (neutral to moderately alkaline). There was significant variation in $\mathrm{pH}$ across sampling districts $(p<0.05)$ : the district Hunza-N had the highest $\mathrm{pH}$ value (8.07), while Astor had the lowest $\mathrm{pH}$ at 6.99. Particle size analysis demonstrated that soils in all districts were largely sandy loams apart from one site each in Hunza-N (N13) and Skardu (S24) where the soils were silty loams and medium loams, respectively (Table 1).

All the sampling districts had average soil inorganic carbon (SIC) contents of $<1 \%$, but it varied significantly between sampling districts $(p<0.05)$. Districts Astor and Hunza-N accounted for the lowest and highest mean SIC contents of $0.001 \%$ and $0.726 \%$, respectively. Some individual sites in Gilgit, Diamer 
and Astor did not have measurable SIC (Table 1) reflecting the highly diverse geology of the parent material. Soil organic carbon (SOC) across all sites was relatively low and ranged from 0.410 to $2.77 \%$ with a significant difference observed among districts ( $p<0.05$ ); Hunza-N had the highest SOC content of 2.34\%. The other four districts, i.e. Gilgit, Diamer, Astor and Skardu, had mean values of $1.20 \%, 1.14 \%$, $1.57 \%$ and $1.31 \%$ SOC, respectively. The sampling sites with relatively higher SOC had more numerous perennial fruit orchards, possibly reflecting inputs of plant residues and lack of ploughing which would tend to produce greater concentrations of soil humus. Combined metal oxides of $\mathrm{Fe}, \mathrm{Mn}$ and $\mathrm{Al}$ showed a significant variation among districts $(p<0.05)$ and fell in the range of 2.22 to $7.75 \mathrm{~g} \mathrm{~kg}^{-1}$. Oxides of $\mathrm{Mn}$ and $\mathrm{Al}$ were less than $1.0 \mathrm{~g} \mathrm{~kg}^{-1}$ in all samples, and concentration of Fe oxides was $5.02 \mathrm{~g} \mathrm{~kg}^{-1}$ in Hunza$\mathrm{N}$ samples; the remaining four districts, i.e. Gilgit, Diamer, Astor and Skardu, had average Fe oxide concentrations of $3.11,2.86,2.89$ and $3.20 \mathrm{~g} \mathrm{~kg}^{-1}$, respectively.

\section{Iodine in soil}

\section{Total soil iodine}

Concentrations of total soil iodine $\left(\mathrm{I}_{\mathrm{T}}\right)$ fell in the range of $273-1180 \mu \mathrm{g} \mathrm{kg}^{-1}$ with an average value of $685 \mu \mathrm{g} \mathrm{kg}^{-1}$ across all sites (Table 2). Average $\mathrm{I}_{\mathrm{T}}$ concentrations in each district, i.e. Gilgit, Diamer, Hunza-N, Astor and Skardu were 674, 895, 650, 489 and $725 \mu \mathrm{g} \mathrm{kg}^{-1}$, respectively, and showed no significant regional differences $(p>0.05)$. Values of $\mathrm{I}_{\mathrm{T}}$ were low compared to (i) the reported global mean value of $2600 \mathrm{~m} \mathrm{~kg}^{-1}$ (ii) the average value $\left(920 \mu \mathrm{g} \mathrm{kg}^{-1}\right)$ reported for soils from other parts of Pakistan (Zia et al., 2014) (iii) values reported by Karim (2018) for the Kurdistan region of Iraq (4140 $\mathrm{\mu} \mathrm{kg} \mathrm{k}^{-1}$ ) and (iv) alluvium-derived soils worldwide $\left(3560 \mu \mathrm{g} \mathrm{kg}^{-1}\right)$ (Johnson, 2003); soils in GilgitBaltistan are largely alluvial in nature (Malik \& Azam, 2009).

The majority of I in soils is generally derived from oceanic sources through atmospheric dry deposition and rainfall (Fuge \& Johnson, 2015). Soil characteristics such as $\mathrm{pH}$, texture and organic matter control retention and, over time, the concentration of total soil I (Bowley et al., 2019; Fuge \& Johnson, 2015;
Humphrey et al., 2020; Maity et al., 2017; Watts et al., 2019). Gilgit-Baltistan is far from the coast and located in the rain shadow area of the Himalayan mountains. Thus, the majority of soil I is believed to be geogenic, derived from the soil parent material. The igneous and metamorphic geology of the region (Malik \& Azam, 2009) has less I than sedimentary rocks (Cox \& Arai, 2014; Fuge \& Johnson, 2015; Hou et al., 2009; Johnson, 2003). The input to soil $\mathrm{I}_{\mathrm{T}}$ from irrigation water is likely to be minimal because of the low concentration of I in water sources. Furthermore, the soils are predominantly sandy with low organic carbon concentrations, which limits the ability of the soils to retain I (Johnson, 2003; Johnson et al., 2003; Köhler et al., 2019; Mohiuddin et al., 2019; Watts \& Mitchell, 2009; Watts et al., 2019). The alkaline nature of the soils would also limit I retention; adsorption of I onto $\mathrm{Fe}$ and $\mathrm{Al}$ oxyhydroxides and rates of conversion to humus-bound I, are both lower under alkaline conditions (Johnson et al., 2003; Shetaya et al., 2012; Söderlund et al., 2017; Wang et al., 2019; Watts \& Mitchell, 2009).

Principal component analysis (PC1 and PC2) revealed that various soil characteristics, especially those related to soil texture, accounted for $60 \%$ variation in soil I concentration (Fig. 2). No relationship was observed between the concentrations of metal oxides and I in all samples $(p>0.05)$; metal oxides are considered to be an important adsorption site for I in soil, but adsorption is most effective at low pH values ( < 5) (Bowley et al., 2019; Humphrey et al., 2020; Schmitz \& Aumann, 1994; Shetaya et al., 2012; Whitehead, 1973). Soil pH did not show a correlation with $\mathrm{I}_{\mathrm{T}}$ in the majority of sampling districts except Skardu which showed a negative correlation (Pearson $r=-0.961, p=0.009, n=5$ ) between soil $\mathrm{pH}$ and $\mathrm{I}_{\mathrm{T}}$. The absence of correlation between soil $\mathrm{pH}$ and $\mathrm{I}_{\mathrm{T}}$ may simply be due to the narrow range of $\mathrm{pH}$ of the soils, as suggested by Karim (2018) for soils in the Iraqi region of Kurdistan with a $\mathrm{pH}$ range similar to that of this study. However, it is contrary to the findings of Zia et al., (2014), Watts et al., (2015) and Bowley et al., (2019) who reported a negative correlation in soils of Pakistan, Malawi and Northern Ireland, respectively. A positive correlation ( $r=0.900, p=0.037$ ) between SOC and $\mathrm{I}_{\mathrm{T}}$ was only observed in Skardu. Soil humus is important for retaining soil I; however, the narrow range of SOC $(<3 \%)$ in all samples may have masked any 
Table 2 Concentration of iodine in soil fractions and its extractability as a proportion of total soil iodine $\left(\mathrm{I}_{\mathrm{T}}\right)$

\begin{tabular}{|c|c|c|c|c|c|c|}
\hline District & Sample code & $\begin{array}{l}\mathrm{I}_{\mathrm{T}} \\
(\mu \mathrm{g} \mathrm{k}\end{array}$ & $\mathrm{I}_{\mathrm{sol}}$ & $\mathrm{I}_{\mathrm{ads}}$ & $\begin{array}{l}\mathrm{I}_{\text {sol }} \text { extractability } \\
(\%)\end{array}$ & $\mathrm{I}_{\mathrm{ads}}$ extractability \\
\hline \multirow[t]{5}{*}{ Gilgit } & G01 & 796 & 17.5 & 20.3 & 2.20 & 2.54 \\
\hline & G02 & 784 & 14.3 & 19.5 & 1.83 & 2.48 \\
\hline & G03 & 391 & 9.93 & 8.87 & 2.54 & 2.27 \\
\hline & G04 & 454 & 9.44 & 12.6 & 2.08 & 2.78 \\
\hline & G05 & 944 & 14.3 & 18.8 & 1.52 & 2.00 \\
\hline \multirow[t]{5}{*}{ Diamer } & D06 & 813 & 21.9 & 19.5 & 2.70 & 2.40 \\
\hline & D07 & 1080 & 23.1 & 28.6 & 2.13 & 2.65 \\
\hline & D08 & 1027 & 24.7 & 29.0 & 2.40 & 2.83 \\
\hline & D09 & 1072 & 15.4 & 18.8 & 1.44 & 1.75 \\
\hline & D10 & 482 & 11.3 & 10.2 & 2.33 & 2.11 \\
\hline \multirow[t]{6}{*}{ Hunza-N } & N11 & 611 & 13.9 & 17.8 & 2.28 & 2.92 \\
\hline & H12 & 877 & 15.1 & 15.4 & 1.73 & 1.76 \\
\hline & N13 & 871 & 12.3 & 16.9 & 1.42 & 1.94 \\
\hline & H14 & 393 & 8.63 & 9.62 & 2.20 & 2.45 \\
\hline & H15 & 596 & 8.15 & 10.2 & 1.37 & 1.70 \\
\hline & N16 & 555 & 8.89 & 10.6 & 1.60 & 1.91 \\
\hline \multirow[t]{5}{*}{ Astor } & A17 & 445 & 7.32 & 10.3 & 1.64 & 2.32 \\
\hline & A18 & 492 & 8.38 & 12.2 & 1.70 & 2.48 \\
\hline & A19 & 273 & 7.39 & 10.5 & 2.71 & 3.83 \\
\hline & A20 & 679 & 10.1 & 14.6 & 1.49 & 2.15 \\
\hline & A21 & 558 & 6.66 & 11.8 & 1.19 & 2.11 \\
\hline \multirow[t]{5}{*}{ Skardu } & $\mathrm{S} 22$ & 742 & 15.9 & 17.9 & 2.14 & 2.42 \\
\hline & $\mathrm{S} 23$ & 1177 & 9.48 & 15.9 & 0.81 & 1.35 \\
\hline & $\mathrm{S} 24$ & 728 & 14.6 & 20.0 & 2.00 & 2.74 \\
\hline & $\mathrm{S} 25$ & 387 & 8.30 & 10.5 & 2.14 & 2.71 \\
\hline & S26 & 590 & 8.38 & 11.9 & 1.42 & 2.01 \\
\hline
\end{tabular}

underlying causal relationship. Fuge and Johnson (1986), Johnson et al., (2002), Zia et al., (2014), Watts et al., (2015) and Bowley et al., (2019) all reported a positive correlation between the concentrations of soil organic matter and I in samples from the UK, Morocco, Pakistan, Malawi and Northern Ireland, respectively. However, Karim (2018) reported no correlation with SOC in soils from Iraqi Kurdistan.

\section{Fractionation of soil iodine}

Soluble iodine The soluble fraction of I ( $\mathrm{I}_{\text {sol }}$, extracted with $\left.0.01 \mathrm{M} \quad \mathrm{KNO}_{3}\right)$ accounted for $\leq 3 \%$ of $\mathrm{I}_{\mathrm{T}}$ in all samples (Table 2). It ranged from 6.66 to $24.7 \mu \mathrm{g} \mathrm{kg}^{-1}$ with an overall median of $10.7 \mu \mathrm{g} \mathrm{kg}^{-1}$. While the concentration of $\mathrm{I}_{\text {sol }}$ varied between samples, the proportion of $\mathrm{I}_{\mathrm{T}}$ that was extractable in $0.01 \mathrm{M} \mathrm{KNO}_{3}$ was almost the same in each district and did not reveal significant differences between districts $(p>0.05)$. The small percentage of $\mathrm{I}_{\mathrm{T}}$ available as $\mathrm{I}_{\text {sol }}$ (Table 2) is comparable with other studies. It was reported that that only $1-12 \%$ of I was water-soluble in soil samples from Dagestan, USSR (Johnson, 2003). Fuge and Johnson (1986) reported that less than $10 \%$ of $\mathrm{I}_{\mathrm{T}}$ was extractable with water in approximately $80 \%$ of soils mainly from Wales $(n=183)$. Soils from other parts of Pakistan (Zia et al., 2014) and other countries such as Ukraine (Duborska et al., 2020; Hou et al., 2009), Sweden (Hou et al., 2009), Denmark (Hansen et al., 2011), Malawi (Watts et al., 2015), Kurdistan (Karim, 2018) and Slovakia (Duborska et al., 2020) have revealed similar average proportions of water-soluble I concentrations: $2.36 \%, 12.7 \%, 3 \%, 4.8 \%, 1.38 \%, 1.59 \%$ and $4.4 \%$ of total soil I, respectively. Small proportions of water soluble I have also been measured for German soils 
$\left(<4 \%\right.$ of $\mathrm{I}_{\mathrm{T}}$ ) (Hou et al., 2009; Humphrey et al., 2018; Schmitz \& Aumann, 1994).

Soil characteristics including $\mathrm{pH}$ and SOC did not show a relationship with $\mathrm{I}_{\text {sol }}$. It is possible that variation in $\mathrm{I}_{\text {sol }}$ concentration across different districts may be due to the variation in I concentration in irrigation water. The concentration of I in irrigation water showed a positive correlation with $\mathrm{I}_{\text {sol }}$ ( $r=0.599, p=0.001)$ when samples of all districts were considered as one data set (Fig. 3).

Adsorbed iodine The adsorbed fraction of soil iodine ( $\mathrm{I}_{\text {ads }}$, extracted with $0.016 \mathrm{M} \mathrm{KH}_{2} \mathrm{PO}_{4}$ ) ranged from 8.87 to $29.0 \mu \mathrm{g} \mathrm{kg}^{-1}$ and had a median concentration of $15.0 \mu \mathrm{g} \mathrm{kg}^{-1}$. It comprised $<4.0 \%$ of $\mathrm{I}_{\mathrm{T}}$ on average for all samples. Shetaya et al., (2012) and Karim (2018) reported a slightly higher ratio of $1-9 \%$ and $10.7 \%$ present as $I_{a d s}$ in their fractionation experiments on soils from the UK and Kurdistan region of Iraq, respectively. As a percentage of $\mathrm{I}_{\mathrm{T}}, \mathrm{I}_{\mathrm{ads}}$ varied across the sampling districts but showed no significant correlation with soil properties $(p>0.05)$, probably because of similar soil properties that might affect I adsorption (SOC, oxide content, clay content and pH) (Bowley et al., 2019; Duborska et al., 2020; Humphrey et al., 2018, 2020; Medrano-Macías et al., 2016).

The kd value for I (Eq. 1) was very low $(1.07 \pm 0.274)$, probably due to coarse texture and low organic carbon contents, suggesting very limited buffering of available soil I against leaching losses and plant uptake.



Fig. 3 Relationship between iodine in irrigation water and soluble soil iodine $\left(\mathrm{I}_{\mathrm{sol}}\right)$ in all samples as one dataset
Speciation of soil iodine

Iodine speciation was carried out on the soluble and adsorbed fractions. In all of the districts most of the I in both $I_{\text {sol }}$ and $I_{\text {ads }}$ fractions was present as organic $I$ (Tables 3 and 4). The median concentrations of organic I in the soluble and adsorbed fractions were 10.4 and $13.8 \mu \mathrm{g} \mathrm{kg}^{-1}$ which accounted for $98 \%$ and $90 \%$ of the $I_{\text {sol }}$ and $I_{a d s}$, respectively, across all samples. The large proportion of organic I is comparable with findings from other studies. $\mathrm{Hu}$ et al., (2007) reported that a large proportion of I (>90\%) in soils is present bound to humic and fulvic acids in samples from USA. Bowley et al., (2016, 2019) and Humphrey et al., (2020) also reported higher concentration of organic I compared to inorganic I in soils from the UK. The ratio of inorganic species, iodide $\left(\mathrm{I}^{-}\right)$and iodate $\left(\mathrm{IO}_{3}{ }^{-}\right)$, was variable across the samples and inconsistent within different districts (supplementary information Table B2 and B3). However, on average, $\mathrm{I}^{-}$generally accounted for a larger proportion of inorganic $\mathrm{I}$ in both $\mathrm{I}_{\mathrm{sol}}(63 \%)$ and $\mathrm{I}_{\mathrm{ads}}$ (84\%) fractions across all districts; this is comparable to other studies such as Yamada et al., (1999), Hu et al., (2005) and Hu etal., (2007). Iodate is sorbed more strongly in most soils than $\mathrm{I}^{-}$and is therefore less easily extracted (Fuge \& Johnson, 2015; Hu et al., 2005, 2007; Humphrey et al., 2020). The other reason for a larger $\mathrm{I}^{-}$presence is probably its stability in the soil solution. Iodide is the dominant inorganic species in most soil solutions because of its stability over a wide range of Eh and $\mathrm{pH}$ values (Söderlund et al., 2011; Cox \& Arai, 2014).

Selenium in soil

\section{Total soil selenium}

The average total soil Se concentration $\left(\mathrm{Se}_{\mathrm{T}}\right)$ across all districts was $209 \mu \mathrm{g} \mathrm{kg}^{-1}$ and ranged from 92.7 to $453 \mu \mathrm{g} \mathrm{kg}^{-1}$ (Table 3). Hunza-N district had the highest mean $\mathrm{Se}_{\mathrm{T}}$ of $346 \mu \mathrm{g} \mathrm{kg}^{-1}$ and was significantly different from the other four districts $(p<0.05)$. The districts of Gilgit, Diamer, Astor and Skardu had mean $\mathrm{Se}_{\mathrm{T}}$ concentrations of 190, 132, 143 and $208 \mu \mathrm{g} \mathrm{kg}^{-1}$, respectively, which were not significantly different from each other $(p>0.05)$. All sites had $\mathrm{Se}_{\mathrm{T}}$ concentrations less than the global mean of $400 \mu \mathrm{g} \mathrm{kg}^{-1}$ (Fordyce et al., 2000; Xing et al., 
Table 3 Concentration of selenium in soil fractions and its extractability as a proportion of total soil selenium $\left(\mathrm{Se}_{\mathrm{T}}\right)$

\begin{tabular}{|c|c|c|c|c|c|c|c|c|}
\hline District & Sample code & $\begin{array}{l}\mathrm{Se}_{\mathrm{T}} \\
(\mu \mathrm{g} \mathrm{l}\end{array}$ & $\mathrm{Se}_{\text {sol }}$ & $\mathrm{Se}_{\mathrm{ads}}$ & $\mathrm{Se}_{\mathrm{TMAH}}$ & $\begin{array}{l}\mathrm{Se}_{\mathrm{sol}} \\
\left(\% \mathrm{Se}_{\mathrm{T}}\right)\end{array}$ & $\mathrm{Se}_{\mathrm{ads}}$ & $\mathrm{Se}_{\mathrm{TMAH}}$ \\
\hline \multirow[t]{5}{*}{ Gilgit } & G01 & 168 & 2.12 & 3.09 & 83.6 & 1.26 & 1.83 & 49.6 \\
\hline & G02 & 165 & 2.00 & 3.28 & 92.0 & 1.21 & 1.99 & 55.7 \\
\hline & G03 & 289 & 4.45 & 4.26 & 139 & 1.54 & 1.47 & 48.0 \\
\hline & G04 & 123 & 1.65 & 2.25 & 51.4 & 1.34 & 1.83 & 41.8 \\
\hline & G05 & 202 & 2.78 & 4.09 & 149 & 1.38 & 2.03 & 73.9 \\
\hline \multirow[t]{5}{*}{ Diamer } & D06 & 109 & 2.11 & 2.25 & 54.3 & 1.93 & 2.06 & 49.7 \\
\hline & D07 & 199 & 3.41 & 4.61 & 106 & 1.72 & 2.32 & 53.1 \\
\hline & D08 & 143 & 1.79 & 1.91 & 59.7 & 1.25 & 1.34 & 41.9 \\
\hline & D09 & 120 & 1.33 & 1.26 & 70.7 & 1.12 & 1.05 & 59.2 \\
\hline & D10 & 92.7 & 1.07 & 1.00 & 32.4 & 1.15 & 1.08 & 34.9 \\
\hline \multirow[t]{6}{*}{ Hunza-N } & N11 & 430 & 5.11 & 7.41 & 177 & 1.19 & 1.72 & 41.1 \\
\hline & H12 & 329 & 2.08 & 1.99 & 106 & 0.631 & 0.604 & 32.2 \\
\hline & N13 & 453 & 6.52 & 7.82 & 293 & 1.44 & 1.73 & 64.6 \\
\hline & H14 & 333 & 4.65 & 4.77 & 165 & 1.40 & 1.44 & 49.5 \\
\hline & H15 & 265 & 2.20 & 1.62 & 108 & 0.830 & 0.613 & 40.6 \\
\hline & N16 & 265 & 2.52 & 1.98 & 126 & 0.951 & 0.748 & 47.5 \\
\hline \multirow[t]{5}{*}{ Astor } & A17 & 151 & 1.57 & 1.13 & 66.8 & 1.04 & 0.749 & 44.2 \\
\hline & A18 & 135 & 1.64 & 1.47 & 65.2 & 1.22 & 1.09 & 48.4 \\
\hline & A19 & 150 & 1.42 & 1.70 & 57.0 & 0.948 & 1.14 & 38.1 \\
\hline & A20 & 172 & 1.22 & 1.26 & 61.7 & 0.708 & 0.729 & 35.8 \\
\hline & A21 & 109 & 0.951 & 0.987 & 47.8 & 0.87 & 0.907 & 43.9 \\
\hline \multirow[t]{5}{*}{ Skardu } & $\mathrm{S} 22$ & 178 & 3.67 & 2.21 & 91.3 & 2.06 & 1.24 & 51.3 \\
\hline & $\mathrm{S} 23$ & 219 & 1.87 & 2.01 & 146 & 0.852 & 0.919 & 66.7 \\
\hline & S24 & 279 & 3.82 & 5.21 & 128 & 1.37 & 1.87 & 46.1 \\
\hline & $\mathrm{S} 25$ & 216 & 2.82 & 2.51 & 82.6 & 1.31 & 1.17 & 38.3 \\
\hline & S26 & 151 & 1.40 & 0.944 & 45.5 & 0.927 & 0.626 & 30.2 \\
\hline
\end{tabular}

2015) except two locations in Hunza-N (N11 and N13) (Table 3). The generally low $\mathrm{Se}_{\mathrm{T}}$ concentrations in the area probably reflect the geology of the area, the sandy soil texture and low organic carbon concentrations. The geology of the study area is dominated by metamorphic and igneous rocks, which usually contain less Se compared to sedimentary rocks (Alexander, 2015; Fordyce et al., 2010, 2013; Koljonen, 1973). Underlying rock type has a major role in Se concentration in most soils (Fordyce, 2007, 2013; Fordyce et al., 2009). Principal components analysis revealed that a sandy soil texture was found to be negatively correlated with $\mathrm{Se}_{\mathrm{T}}$ concentration (Fig. 2). Sandy soils generally retain less Se compared to clayey soils (Antanaitis et al., 2008; Lopes et al., 2017), and organic carbon plays an important role in retaining soil Se (Gustafsson et al., 1993; Jones et al., 2017; Li, Liang, et al., 2017; Lopes et al., 2017;
Supriatin et al., 2016; Xing et al., 2015). The slightly greater $\mathrm{Se}_{\mathrm{T}}$ in two sites (N11 and N13) may be a localised effect possibly reflecting long-term use of irrigation water; the corresponding irrigation waters of N11 and N13 had relatively high Se concentrations.

Moreover, soils from these sites had relatively high organic carbon contents compared to other sites. In most cases, the contribution to $\mathrm{Se}_{\mathrm{T}}$ in soils from seasonal irrigation is likely to be low because of the generally low $\mathrm{Se}_{\mathrm{w}}$ concentrations in irrigation water and the predominance of soluble $\mathrm{Se}^{\mathrm{VI}}$ in water. Soil organic carbon had a positive correlation $(r=0.509$, $p<0.005)$ with $\mathrm{Se}_{\mathrm{T}}$ for all data considered together, but there was no correlation for intra-district data (Fig. 4). This could be the result of small sample sizes and a narrow range of $\%$ SOC in each district. The SIC also showed a positive correlation $(r=0.668$, $p<0.001)$ with $\mathrm{Se}_{\mathrm{T}}$ and with the soil Se fractions 


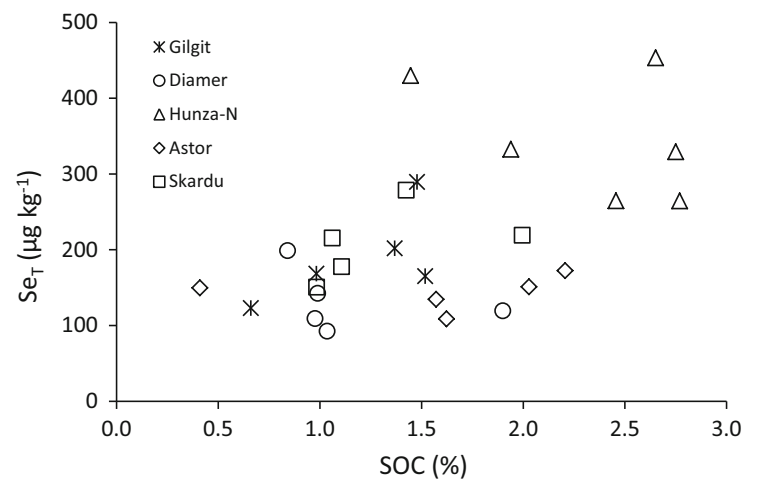

Fig. 4 Correlation between concentrations of soil organic carbon (SOC) and total soil selenium $\left(\mathrm{Se}_{\mathrm{T}}\right)$

(soluble, adsorbed and humus-bound) for the whole set of data but again there were no significant correlations for the intra-district data.

The majority of the soils in this study were marginally deficient in Se based on the threshold values for Se deficiency $\left(<125 \mu \mathrm{g} \mathrm{kg}^{-1}\right)$ and marginal deficiency $\left(>125-175 \mu \mathrm{g} \mathrm{kg}^{-1}\right)$ in soils reported by Fordyce et al., (2009). The typically low $\mathrm{Se}_{\mathrm{T}}$ concentrations in the area are in the range for sandy soils reported in other parts of the world. For example, sandy soils in Poland, Lithuania, Russia, Finland and Canada had 140, 140, 180, 210 and $270 \mu \mathrm{g} \mathrm{kg}^{-1}$ of $\mathrm{Se}_{\mathrm{T}}$, respectively (Kabata-Pendias \& Mukherjee, 2007). Watts et al., (2010) reported $300 \mu \mathrm{g} \mathrm{kg}^{-1} \mathrm{Se}$ in a mountainous area of San Juan in Argentina which is in a similar range to this study. Similarly, Chilimba et al., (2011) reported an average Se concentration of $194 \mu \mathrm{g} \mathrm{kg}^{-1}$ in Malawian soils which is typical of the region due to its geology and advanced weathering of many landscapes.

\section{Fractionation of soil selenium}

Soluble selenium The soluble $\mathrm{Se}$ fraction $\left(\mathrm{Se}_{\mathrm{sol}}\right.$, extracted with $\left.0.01 \mathrm{M} \mathrm{KNO}_{3}\right)$ ranged from 0.95 to $6.52 \mu \mathrm{g} \mathrm{kg}^{-1}$ with mean and median values of 2.54 and $2.09 \mu \mathrm{g} \mathrm{kg}^{-1}$. A significant variation in $\mathrm{Se}_{\text {sol }}$ was seen between districts $(p<0.05)$. The districts of Hunza-N and Astor had the highest $\left(3.84 \mu \mathrm{g} \mathrm{kg}^{-1}\right.$ ) and lowest $\left(1.36 \mu \mathrm{g} \mathrm{kg}^{-1}\right)$ values of $\mathrm{Se}_{\mathrm{sol}}$, respectively. Districts Skardu, Gilgit and Diamer had mean $\mathrm{Se}_{\text {sol }}$ values of $2.71,2.60$ and $1.94 \mu \mathrm{g} \mathrm{kg}^{-1}$, respectively. The concentration of $\mathrm{Se}_{\mathrm{sol}}$ as a percentage of soil $\mathrm{Se}_{\mathrm{T}}\left(\% \mathrm{Se}_{\mathrm{sol}}\right)$ was very low and typically accounted for $<2 \%$ of $\mathrm{Se}_{\mathrm{T}}$ across all sites (Table 3 ). There was no significant variation between districts $(p>0.05)$ which also suggests $\% \mathrm{Se}_{\mathrm{sol}}$ was independent of soil $\mathrm{Se}_{\mathrm{T}}$. The low extractability of $\mathrm{Se}_{\mathrm{sol}}$ in soils is comparable with other studies. Karim (2018) used the same sequential extraction procedure and found that $\% \mathrm{Se}_{\mathrm{sol}}$ ranged from 0.096 to $2.18 \%$ in Kurdistan soils. Wang et al., (2012) reported $<1 \%$ of soluble Se in agriculture soils of Shaanxi province in China. Tan etal., (2002) and Xing et al., (2015) studied the concentration of water soluble Se in different soil types in China and found it varied from 1.07-6.69\% and $0.28-1.45 \%$, respectively. The use of a parallel single extraction method on soils from the UK showed that water-soluble Se accounted for $1.4-14 \%$ of the total soil Se (Tolu et al., 2011). Keskinen et al., (2009) studied the fate of residual Se in Finland soils, amended with $\mathrm{Se}$ fertilizers and observed that soluble Se account for approximately $1 \%$ of $\mathrm{Se}_{\mathrm{T}}$. Similarly, Ligowe et al., (2020) investigated the fate of residual isotopically labelled ${ }^{77} \mathrm{Se}$ fertilizer in Malawian soils, using the same sequential extraction procedure as used in the current study and found that the soluble fraction of Se accounted for $\sim 3 \%$ of total ${ }^{77}$ Se applied in the preceding year.

Adsorbed selenium Adsorbed $\mathrm{Se}\left(\mathrm{Se}_{\mathrm{ads}}\right)$ may represent the $\mathrm{Se}$ fraction associated with metal oxides. The range of $\mathrm{Se}_{\mathrm{ads}}$ concentrations (0.944-7.82 $\left.\mu \mathrm{g} \mathrm{kg}^{-1}\right)$ was similar to that of $\mathrm{Se}_{\mathrm{sol}}$ (Table 3); the average $\mathrm{Se}_{\mathrm{ads}}$ in all samples was $2.81 \mu \mathrm{g} \mathrm{kg}^{-1}$. A significant variation in $\mathrm{Se}_{\text {ads }}$ concentration among districts was observed with Hunza-N exhibiting the highest mean value of $4.27 \mu \mathrm{g} \mathrm{kg}^{-1}$. The average concentrations in other districts (Gilgit, Skardu, Diamer and Astor) were 3.39, 2.58, 2.20 and $1.31 \mu \mathrm{g} \mathrm{kg}^{-1}$, respectively. Adsorbed $\mathrm{Se}$ as a percentage of soil $\mathrm{Se}_{\mathrm{T}}\left(\% \mathrm{Se}_{\mathrm{ads}}\right)$ was not significantly different from that of $\mathrm{Se}_{\mathrm{sol}}(p>0.05)$. For all samples, $\mathrm{Se}_{\mathrm{ads}}$ recovery ranged from 0.604 to $2.32 \%$ and had a mean value of $1.31 \%$. The average values of $\% \mathrm{Se}_{\mathrm{ads}}$ for Gilgit, Diamer, Skardu, Hunza-N and Astor were 1.83, 1.57, 1.17, 1.14 and $0.923 \%$, respectively. The low recovery of $\mathrm{Se}_{\mathrm{ads}}$ is comparable with other investigations. Ligowe et al., (2020) reported an average $\mathrm{Se}_{\mathrm{ads}}$ recovery of $<3 \%$ in Malawian soils. Karim (2018) reported a comparable range of $\% \mathrm{Se}_{\mathrm{ads}}$ with a mean value of $1.88 \%$ in 97 soil samples from Kurdistan. Mathers (2015) determined 
$\% \mathrm{Se}_{\mathrm{ads}}$ for 78 Malawi and $236 \mathrm{UK}$ soils and reported values of $3.12 \%$ and $2.62 \%$, respectively. The results of a Malawi national survey, including 87 soil samples, reported $\% \mathrm{Se}_{\text {ads }}$ values of $<1-8 \%$ (Chilimba et al., 2011); Stroud et al., (2012) reported $\% \mathrm{Se}_{\text {ads }}$ values of $1.1-3.4 \%$ for UK soils. Some studies have also reported higher levels of $\% \mathrm{Se}_{\mathrm{ads}}$ : Tolu et al., (2011) measured $20 \%$ in a clay loam soil from the UK; Schilling et al., (2011) and Schilling etal., (2014) reported $12-35 \%$ and $12-27 \%$ in German and Indian soils, respectively; Keskinen et al., (2009) found 15-20\% in Finnish soils.

Humus-bound selenium Concentrations of humusbound $\mathrm{Se}\left(\mathrm{Se}_{\mathrm{TMAH}}\right)$ ranged from 32.4 to $293 \mu \mathrm{g} \mathrm{kg}^{-1}$ with an average value of $100 \mathrm{~g} \mathrm{~kg} \mathrm{k}^{-1}$ considering all samples together (Table 3). There was a significant variation between districts; concentrations in Hunza-N, Gilgit, Skardu, Diamer and Astor were 162, 103, 98.9, 59.7 and $64.5 \mu \mathrm{g} \mathrm{kg}^{-1}$, respectively. The extractability of $\mathrm{Se}_{\mathrm{TMAH}}$, as a percentage of $\mathrm{Se}_{\mathrm{T}}$, ranged from 30 to $74 \%$ with an overall average of $47 \%$; there was no significant variation between districts $(p>0.05)$. For the majority of samples (65\%), $\mathrm{Se}_{\mathrm{TMAH}}$ was less than $50 \%$ of $\mathrm{Se}_{\mathrm{T}}$. This suggests that a substantial amount of Se is present in a refractory pool, resistant to dissolution in TMAH and extractable only with the $\mathrm{HF}_{-} \mathrm{HClO}_{4}$ $\mathrm{HNO}_{3}$ digestion procedure. This form of Se is likely to be present within mineral structures (Mathers, 2015). Comparable (average) recovery of $\mathrm{Se}_{\mathrm{T}}(41 \%)$ with TMAH was observed in 97 soil samples from Kurdistan (Karim, 2018). A wide range of Se recoveries in soils and sediments using alkaline extractions has been reported, including 50\% (Séby et al., 1997), 29-37\% (Ponce de León et al., 2003), 35-50\% (Keskinen et al., 2009), 31.8-52\% (Qin et al., 2012), 31.9-70.1\% (Schilling et al., 2014), in soils and sediments from Ireland, Canada, Finland, China and India, respectively.

\section{Speciation of soil selenium}

Speciation analysis was performed on both components of 'available $\mathrm{Se}$ ': $\mathrm{Se}_{\mathrm{sol}}$ and $\mathrm{Se}_{\mathrm{ads}}$ extracts (supplementary information Table B4 and B5). A large proportion of $\mathrm{Se}_{\mathrm{sol}}$ was present as organic-Se with an average value of $66.9 \%$ and a range from $43.5 \%$ to $89.9 \%$ considering all samples together. The average proportion of organic $\mathrm{Se}_{\mathrm{sol}}$ did not show significant variation between districts $(p>0.05)$ and consisted of $60.1,65.8,69,75.5$ and $64 \%$ of total $\mathrm{Se}_{\text {sol }}$ in Gilgit, Diamer, Hunza-N, Astor and Skardu, respectively. The soluble organic $\mathrm{Se}$ is probably linked to soil humus acids, but soluble organic Se may also be present in parent materials. Kulp and Pratt (2004) reported that a large proportion of soluble Se was present as organic Se in different rocks from the USA. Similarly, Zhang and Moore (1996) reported a large proportion of the soluble Se fraction in wetland sediments from Montana was organically bound.

In the adsorbed fraction $\left(\mathrm{Se}_{\mathrm{ads}}\right)$, there was a wide variation in speciation with the $\%$ organic Se ranging from 0 to $87 \%$ with a mean value of $39.7 \%$ for the whole data set. There was a significant difference between districts $(p<0.05)$ with Astor and Skardu accounting for the highest $(68.4 \%)$ and lowest (19.2\%), respectively. The proportions of organic $\mathrm{Se}_{\mathrm{ads}}$ in other districts were: $30.6 \%$ (Hunza-N), $32.7 \%$ (Gilgit) and $49.5 \%$ (Diamer). The variation observed in adsorbed organic species is comparable with the results described in Stroud et al., (2010) who reported a range of $30-87 \%$ organic Se in phosphate extracts of soils from different parts of the UK. Similarly, Kulp and Pratt (2004) reported a range of 13.6-85\% organic-Se in phosphate extractions of parent rocks.

The inorganic $\mathrm{Se}$ in $\mathrm{Se}_{\text {sol }}$ and $\mathrm{Se}_{\text {ads }}$ was present as both $\mathrm{Se}^{\mathrm{IV}}$ and $\mathrm{Se}^{\mathrm{VI}}$, but the proportion of inorganic $\mathrm{Se}$ present as $\mathrm{Se}^{\mathrm{IV}}$ in the soluble and adsorbed fractions ranged from $83.7-100 \%$ to $94.1-99.9 \%$, respectively (supplementary information Table B4 and B5); there was no difference between districts $(p>0.05)$. The large proportion of $\mathrm{Se}^{\mathrm{IV}}$ in the soluble inorganic fraction contradicts other investigations in the literature, but for the adsorbed fraction the values were comparable to other studies. Karim (2018) and Wang et al., (2012) reported that inorganic $\mathrm{Se}_{\text {sol }}$ was largely present as $\mathrm{Se}^{\mathrm{VI}}$ in $\mathrm{Se}_{\text {sol }}$ fraction in soils from Kurdistan and China; similarly, Kulp and Pratt (2004) also reported a large proportion of $\mathrm{Se}^{\mathrm{VI}}$ in inorganic $\mathrm{Se}_{\mathrm{sol}}$. The large proportion of $\mathrm{Se}^{\mathrm{IV}}$ in inorganic $\mathrm{Se}_{\text {sol }}$ in the current study could be due to its presence in the geology of the area. By contrast, the large proportion of $\mathrm{Se}^{\mathrm{IV}}$ in inorganic $\mathrm{Se}_{\text {ads }}$ was consistent with other investigations. Karim (2018) found that $96 \%$ of inorganic $\mathrm{Se}_{\text {ads }}$ was present as $\mathrm{Se}^{\mathrm{IV}}$. Similarly, a study of Se speciation and extractability in Dutch agricultural soils found that Se was largely present as $\mathrm{Se}^{\mathrm{IV}}$ in the adsorbed fraction extracted with ammonium oxalate (Supriatin et al., 2016). Wang et al., (2012) 
and Stroud et al., (2010) observed that $\mathrm{Se}^{\mathrm{IV}}$ was the only inorganic species detected in an adsorbed fraction of soil samples from Shaanxi province in China and different parts of the UK, respectively; Kulp and Pratt (2004) reported the presence of only $\mathrm{Se}^{\mathrm{IV}}$ in their adsorbed fraction.

Selenite is strongly adsorbed on soil surfaces compared to $\mathrm{Se}^{\mathrm{VI}}$, but the average $\mathrm{kd}$ value for $\mathrm{Se}^{\mathrm{IV}}$ (Eq. 1) was very low (1.27 \pm 0.214$)$. As suggested for I, this was probably due to the coarse texture and low humus content of the soil.

The low kd value reflects the lack of a substantial buffer mechanism for available Se. Not only is the soluble $\mathrm{Se}_{\text {sol }}$ very low, and mainly organic, but the ability of the soil to replenish Se in solution from $\mathrm{Se}_{\mathrm{ads}}$ following depletion by leaching or plant uptake is also very poor. Taking all the factors above into account, it is clear that the Se status of Gilgit-Baltistan region is exceptionally low.

\section{Conclusions}

The average concentrations of $\mathrm{I}_{\mathrm{T}}$ and $\mathrm{Se}_{\mathrm{T}}$ in GilgitBaltistan soils were 685 and $209 \mu \mathrm{g} \mathrm{kg}^{-1}$, respectively, which are lower than the global average of soil
$\mathrm{I}_{\mathrm{T}}\left(2600 \mu \mathrm{g} \mathrm{kg}^{-1}\right)$ and $\mathrm{Se}_{\mathrm{T}}\left(400 \mu \mathrm{g} \mathrm{kg}^{-1}\right)$, and most of the reported values for $\mathrm{I}_{\mathrm{T}}$ and $\mathrm{Se}_{\mathrm{T}}$ in other parts of the world (Figs. 5 and 6). The concentration of I and Se in soil parent materials (igneous and metamorphic rocks) is low, and the contribution from other sources (marine and rainfall) is likely to be negligible because Gilgit-Baltistan is about $1400 \mathrm{~km}$ away from the nearest sea and is located in a rain shadow region with minimum rainfall. Soils in the area have a coarse texture, low organic carbon and high $\mathrm{pH}$ which restricts their ability to retain $\mathrm{I}$ and $\mathrm{Se}$. The input to soil $\mathrm{I}_{\mathrm{T}}$ and $\mathrm{Se}_{\mathrm{T}}$ from irrigation water is likely to be minimal because of the low concentrations of $\mathrm{I}$ (0.01-1.79 $\left.\mu \mathrm{g} \mathrm{L}^{-1}\right)$ and Se $\left(0.016-2.09 \mu \mathrm{g} \mathrm{L}^{-1}\right)$ in irrigation water. The soluble and adsorbed fractions of soil I and Se, which are considered to be available for plant uptake, accounted for $<7 \%$ and $<3 \%$ of total soil I and Se content, respectively. The distribution coefficient $(\mathrm{kd})$ for $\mathrm{I}(1.07 \pm 0.274)$ and $\mathrm{Se}$ $(1.27 \pm 0.214)$ was very low suggesting very limited buffering of available I against leaching losses and plant uptake. Thus, not only are the $\mathrm{I}_{\text {sol }}$ and $\mathrm{Se}_{\mathrm{Sol}}$ concentrations very low but the ability of the soil to replenish $I$ and $S e$ in solution from $I_{a d s}$ and $S e_{a d s}$ following depletion by leaching or plant uptake is also very poor. Furthermore, I and Se in the soluble and

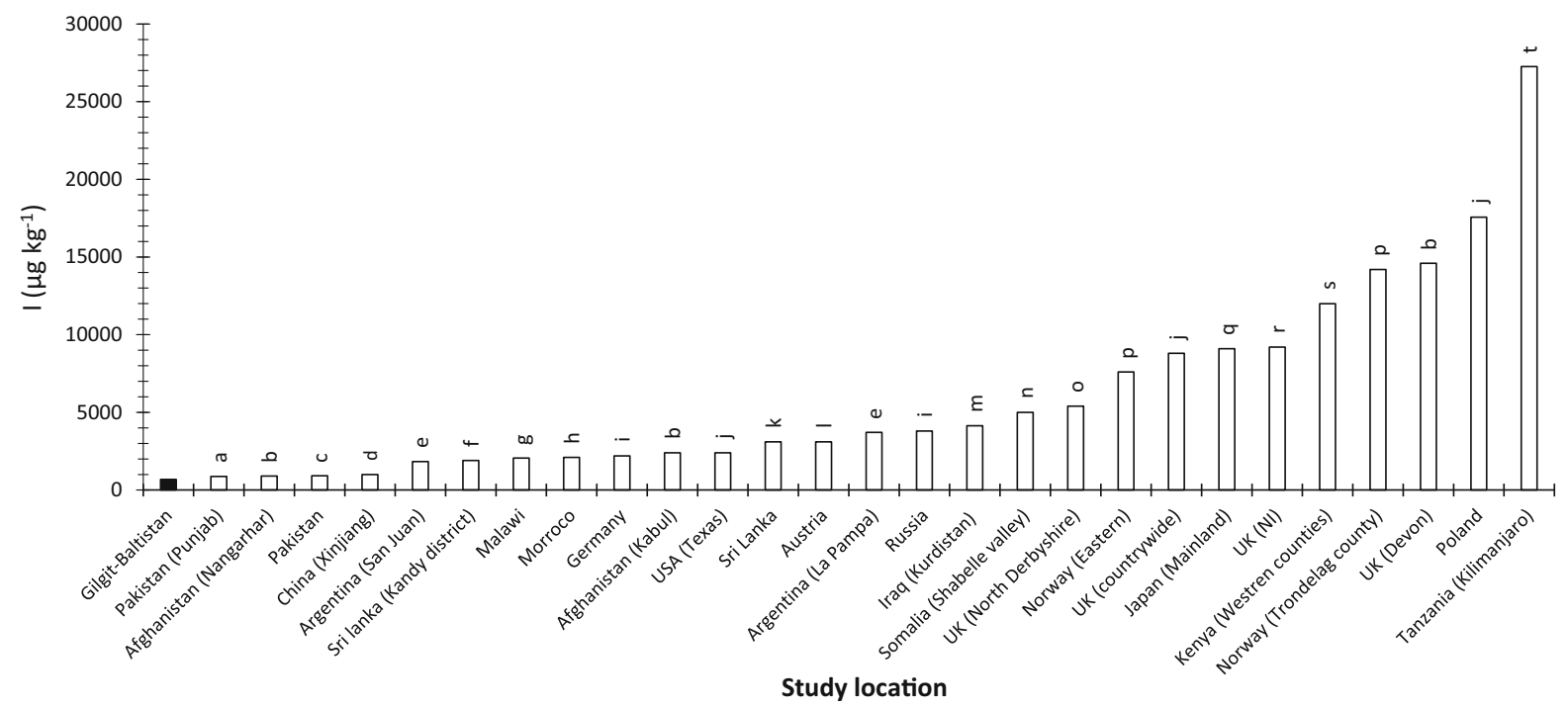

Fig. 5 Comparison of mean Gilgit-Baltistan soil $I_{T}$ with average soil I concentration from other studies worldwide as well as in Pakistan. The dark colour bar represents I concentration in Gilgit-Baltistan soil. Sources ' $\mathrm{Zia}$ et al., 2017; ' ${ }^{\mathrm{b}}$ Watts \& Mitchell, 2009; ${ }^{\mathrm{c}} \mathrm{Zia}$ et al., 2014; ${ }^{\mathrm{d}}$ Fordyce et al., 2003; ' Watts et al., 2010; ${ }^{\mathrm{f}}$ Dissanayake \& Chandrajith,
1996; ' Watts et al., 2015; hohnson et al., 2002; ${ }^{\mathrm{i}}$ Ashworth, 2009; jJohnson, 2003; ' Fordyce et al., 2000; ' Gerzabek et al., 1999; ${ }^{\mathrm{m}}$ Karim, 2018; ${ }^{\mathrm{n}} \mathrm{Ali}, 2020 ;{ }^{\circ}$ Fuge \& Long, $1989 ;{ }^{\mathrm{p}}$ Låg \& Steinnes, 1976; ${ }^{\mathrm{q}}$ Yamasaki et al., 2015; ${ }^{\mathrm{r}}$ Bowley, 2013; ${ }^{\mathrm{t}}$ Watts et al., 2019 


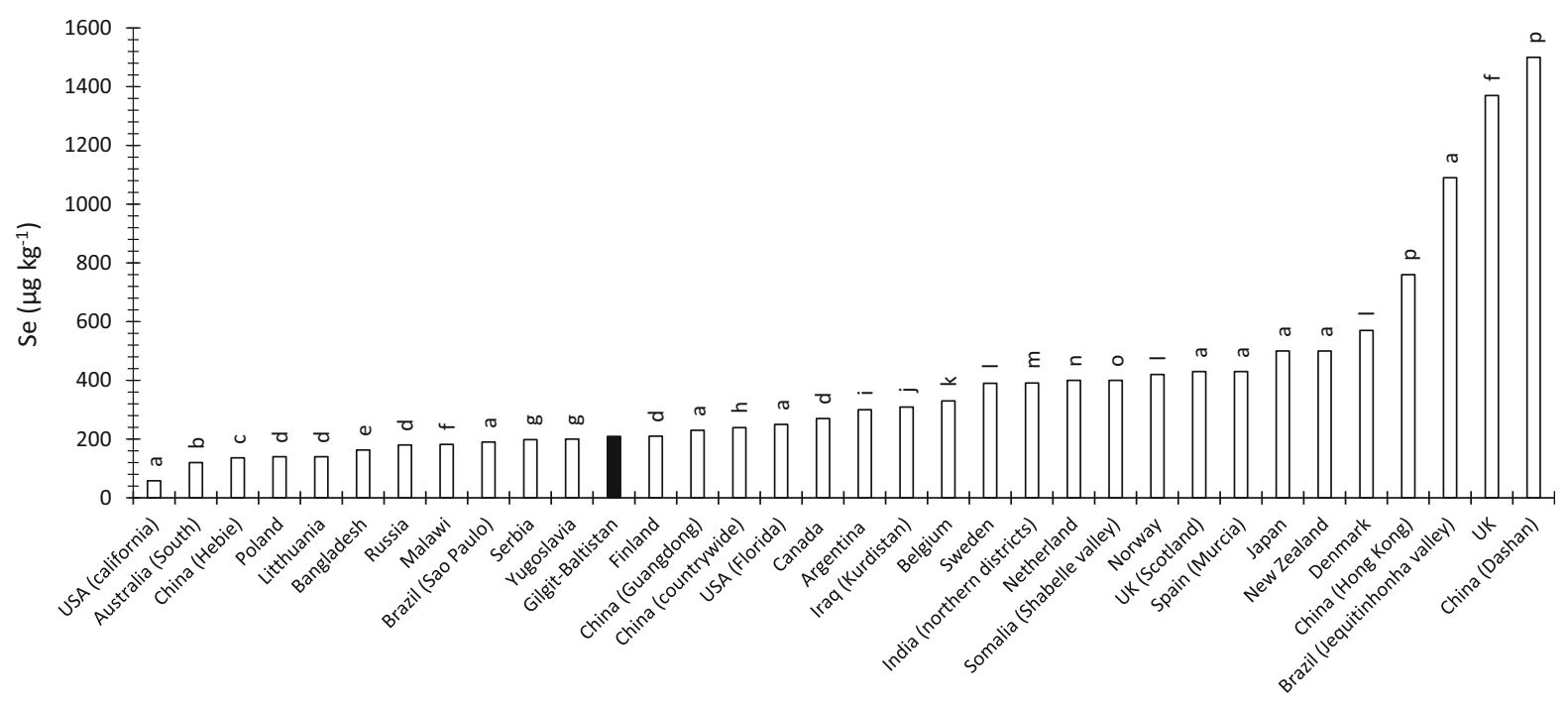

Study location

Fig. 6 Comparison of mean Gilgit-Baltistan soil $\mathrm{Se}_{\mathrm{T}}$ concentration with average soil Se concentration from other studies worldwide. The dark colour bar represents Se concentration in Gilgit-Baltistan soil. Sources ${ }^{a}$ Lopes et al., 2017; ${ }^{b}$ Ramkissoon 2020; ${ }^{c}$ Fordyce et al., 2003; ${ }^{d}$ Kabata-Pendias \& Mukherjee,

adsorbed fractions was predominantly present as organic species which may not be available to plants. All these factors demonstrate that the low status of I and $\mathrm{Se}$ in the Gilgit-Baltistan environment is the product of several co-existing factors.

The low concentration of $\mathrm{I}$ and $\mathrm{Se}$ in GilgitBaltistan soil and water may be reflected in locally grown crops and ultimately in the local population because the population in the area largely consumes locally grown agricultural produce which restricts their access to dietary I and Se form other sources.

Acknowledgement We thank the University of Nottingham for providing financial support for this study.

Funding Financial support for this study was provided by the University of Nottingham.

Data availability The authors confirm that the summary of data supporting the findings of this study is available within the article. Detailed data are available from the corresponding author upon request.

\section{Declarations}

Conflict of interest The authors declare that they have no conflict of interest.
2007; ${ }^{\circ}$ Rahman et al., 2013; ${ }^{f}$ Mathers, 2015; ${ }^{g}$ Maksimovic et al., 1992; ${ }^{h}$ Tan et al., 2002; ${ }^{i}$ Watts et al., 2010; ${ }^{j}$ Karim, 2018; ${ }^{k}$ De Temmerman et al., 2014; ${ }^{l}$ Girling, 1984; ${ }^{m}$ Yadav et al., 2005; ${ }^{n}$ Supriatin et al., 2016; ${ }^{o} \mathrm{Ali}, 2020 ;{ }^{p}$ Xing et al., 2015

Open Access This article is licensed under a Creative Commons Attribution 4.0 International License, which permits use, sharing, adaptation, distribution and reproduction in any medium or format, as long as you give appropriate credit to the original author(s) and the source, provide a link to the Creative Commons licence, and indicate if changes were made. The images or other third party material in this article are included in the article's Creative Commons licence, unless indicated otherwise in a credit line to the material. If material is not included in the article's Creative Commons licence and your intended use is not permitted by statutory regulation or exceeds the permitted use, you will need to obtain permission directly from the copyright holder. To view a copy of this licence, visit http://creativecommons.org/licenses/by/4.0/.

\section{References}

Alexander, J. (2015). Selenium. In: Nordberg, G.F., Fowler, B.A. \& Nordberg, M. (Ed.), Handbook on the Toxicology of Metals (Fourth Edition). San Diego: Academic Press.

Ali, I.R. (2020). Selenium and iodine sorption and fixation on calcareous soils from Somalia. PhD Thesis. University of Nottingham.

Antanaitis, A., Lubyte, J., Antanaitis, S., Staugaitis, G., \& Viskelis, P. (2008). Selenium concentration dependence on soil properties. Journal of Food, Agriculture \& Environment, 6, 163-167

Ashworth, D. J. (2009). Transfers of iodine in the soil-plant-air system: solid-liquid partitioning, migration, plant uptake 
and volatilization. In V. R. Preedy, G. N. Burrow, \& R. Watson (Eds.), Comprehensive handbook of iodine.London: Academic Press Elsevier, London.

Ayers, R.S. \& Westcot, D.W. (1986). Water quality for agriculture. Foood and agriculture organisation of the United Nations.

Barillas, J. R. V., Quinn, C. F., \& Pilon-Smits, E. A. H. (2011). Selenium accumulation in plants-phytotechnological applications and ecological implications. International Journal of Phytoremediation, 13, 166-178

Bortolini, L., Maucieri, C., \& Borin, M. (2018). A tool for the evaluation of irrigation water quality in the arid and semiarid regions. Agronomy, 8, 23

Bowley, H.E. (2013). Iodine dynamics in the terrestrial environment. $\mathrm{PhD}$ Thesis. University of Nottingham.

Bowley, H. E., Young, S. D., Ander, E. L., Crout, N. M. J., Watts, M. J., \& Bailey, E. H. (2016). Iodine binding to humic acid. Chemosphere, 157, 208-214

Bowley, H. E., Young, S. D., Ander, E. L., Crout, N. M. J., Watts, M. J., \& Bailey, E. H. (2019). Iodine bioavailability in acidic soils of Northern Ireland. Geoderma, 348, 97-106

Broadley, M. R., White, P. J., Bryson, R. J., Meacham, M. C., Bowen, H. C., Johnson, S. E., et al. (2006). Biofortification of UK food crops with selenium. Proceedings of the Nutrition Society, 65(2), 169-181.

Bujdoš, M., Mul'ová, A., Kubová, J., \& Medved', J. (2005). Selenium fractionation and speciation in rocks, soils, waters and plants in polluted surface mine environment. Environmental Geology, 47, 353-360

Cary, E. E., \& Gissel-Nielsen, G. (1973). Effect of fertilizer anions on the solubility of native and applied selenium in soil. Soil Science Society of America Journal, 37, 590-593

Chilimba, A. D. C., Young, S. D., Black, C. R., Rogerson, K. B., Ander, E. L., Watts, M. J., Lammel, J., \& Broadley, M. R. (2011). Maize grain and soil surveys reveal suboptimal dietary selenium intake is widespread in Malawi. Scientific Reports, 1,72

Conde, J., \& Alaejos, M. S. (1997). Selenium concentrations in natural and environmental waters. Chemical Reviews, 97, 1979-2004

Cox, E. M., \& Arai, Y. (2014). Environmental chemistry and toxicology of iodine. Advances in Agronomy, 128, 47-96.

Cutter, G. A. (1985). Determination of selenium speciation in biogenic particles and sediments. Analytical Chemistry, 57, 2951-2955

Day, T. K., \& Powell-Jackson, P. R. (1972). Flouride, water hardness and endemic goitre. The Lancet, 299, 1135-1138

De Temmerman, L., Waegeneers, N., Thiry, C., Du Laing, G., Tack, F., \& Ruttens, A. (2014). Selenium content of Belgian cultivated soils and its uptake by field crops and vegetables. Science of The Total Environment, 468-469, $77-82$

Dhillon, K.S., Dhillon, S.K. \& Singh, B. (2019). Genesis of seleniferous soils and associated animal and human health problems. In: Sparks, D.L. (Ed.), Advances in agronomy. Burlington: Academic Press Elsevier.

Dissanayake, C. B., \& Chandrajith, R. L. R. (1996). Iodine in the environment and endemic goitre in Sri Lanka. Geological Society, London, Special Publications, 113, 213-221
Duborska, E., Bujdoš, M., Urik, M., \& Matuš, P. (2020). Iodine fractionation in agricultural and forest soils using extraction methods. CATENA, 195, 104749

Eastman, C.J. \& Zimmermann, M.B. (2018). The iodine deficiency disorders. https:/www.ncbi.nlm.nih.gov/books/ NBK285556/ (Accessed 15 january 2021).

Ebrahimi, N., Stoddard, F. L., Hartikainen, H., \& Seppänen, M. M. (2019). Plant species and growing season weather influence the efficiency of selenium biofortification. Nutrient Cycling in Agroecosystems, 114, 111-124

Faridullah, Ahmad, D., Shabbir, H., Ahmed, T., Irshad, M., Alam, A. \& Sardar, A. (2017). Socio-demographic characters, distribution and transformation of iodine in soil, plant and wheat grains at District Diamer, Gilgit-Baltistan, Pakistan. Environmental Geochemistry and Health, 40, 777-790

Fishbein, L. (1983). Environmental selenium and its significance. Fundamental and Applied Toxicology, 3, 411-419

Fordyce, F. (2007). Selenium geochemistry and health. AMBIO: A Journal of the Human Environment, 36, 94-97.

Fordyce, F.M. (2013). Selenium deficiency and toxicity in the environment. In: Selinus, O., Alloway, B. J., Centeno, J. A., Finkelman, R. B., Fuge, R., Lindh, U. \& Smedley, P. (Ed.), Essentails of medical geology. USA: Springer.

Fordyce, F. M., Brereton, N., Hughes, J., Luo, W., \& Lewis, J. (2010). An initial study to assess the use of geological parent materials to predict the Se concentration in overlying soils and in five staple foodstuffs produced on them in Scotland. Science of The Total Environment, 408, 5295-5305

Fordyce, F.M., Brereton, N., Hughes, J., Reay, G., Thomas, L., Walker, A., Luo, W. \& Lewis, J. (2009). The selenium content of scottish soil and food products. Food Standards Agency Scotland Project S14042.

Fordyce, F. M., Johnson, C. C., Navaratna, U. R. B., Appleton, J. D., \& Dissanayake, C. B. (2000). Selenium and iodine in soil, rice and drinking water in relation to endemic goitre in Sri Lanka. Science of The Total Environment, 263, 127-141

Fordyce, F.M., Stewart, A.G., Ge, X., J-Y, J. \& Cave, M. (2003). Environmental controls in IDD: A case ctudy in the Xinjiang province of China. British Geological Survey Technical Report, CR/01/045N.

Fuge, R., \& Johnson, C. C. (1986). The geochemistry of iodine - a review. Environmental Geochemistry and Health, 8, $31-54$

Fuge, R., \& Johnson, C. C. (2015). Iodine and human health, the role of environmental geochemistry and diet, a review. Applied Geochemistry, 63, 282-302

Fuge, R., \& Long, A. (1989). Iodine in the soils of North Derbyshire. Environmental Geochemistry and Health, 11, 25-29

Fuge, R. (1989). Iodine in waters: possible links with endemic goitre. Applied Geochemistry, 4, 203-208

Fuge, R. (2013). Soils and iodine deficiency. In: Selinus, O., Alloway, B., Centeno, J., Finkelman, R., Fuge, R., Lindh, U. \& Smedley, P. L. (Ed.), Essentials of medical geology: Revised edition. London: Springer.

Gerzabek, M. H., Muramatsu, Y., Strebl, F., \& Yoshida, S. (1999). Iodine and bromine contents of some Austrian soils 
and relations to soil characteristics. Journal of Plant Nutrition and Soil Science, 162, 415-419

Gilfedder, B. S., Petri, M., \& Biester, H. (2009). Iodine speciation and cycling in fresh waters: a case study from a humic rich headwater lake (Mummelsee). Journal of Limnology, 68, 396-408

Girling, C. A. (1984). Selenium in agriculture and the environment. Agriculture, Ecosystems \& Environment, 11, $37-65$

Gupta, M., \& Gupta, S. (2017). An overview of selenium uptake, metabolism, and toxicity in plants. Frontiers in Plant Science, 7, 2074

Gustafsson, J. P., Jacks, G., Stegmann, B., \& Ross, H. B. (1993). Soil acidity and adsorbed anions in Swedish forest soilslong-term changes. Agriculture, Ecosystems \& Environment, 47, 103-115

Hansen, V. (2011). Chemical speciation analysis and environmental behaviour of ${ }^{127} I$ and ${ }^{129} I$. PhD Thesis. Technical University of Denmark.

Hansen, V., Roos, P., Aldahan, A., Hou, X., \& Possnert, G. (2011). Partition of iodine $\left({ }^{129} \mathrm{I}\right.$ and $\left.{ }^{127} \mathrm{I}\right)$ isotopes in soils and marine sediments. Journal of Environmental Radioactivity, 102, 1096-1104

Hetzel, B. (1983). Iodine deficiency disorders (IDD) and their eradication. The Lancet, 322, 1126-1129

Hong, C-L., Weng, H-X., Yan, A-L. \& Xie, L-L. (2007). Characteristics of iodine uptake and accumulation by vegetables. Ying yong sheng tai xue bao $=$ The Journal of Applied Ecology, 18, 2313-2318.

Hou, X., Hansen, V., Aldahan, A., Possnert, G., Lind, O. C., \& Lujaniene, G. (2009). A review on speciation of iodine-129 in the environmental and biological samples. Analytica Chemica, 632, 181-196

Hu, Q., Moran, J.E. \& Blackwood, V. (2007). Geochemical cycling of iodine species in soils. https://inis.iaea.org/ search/search.aspx?orig_q=RN:40026411. Accessed 15 December 2019.

Hu, Q., Zhao, P., Moran, J. E., \& Seaman, J. C. (2005). Sorption and transport of iodine species in sediments from the Savannah river and hanford sites. Journal of Contaminant Hydrology, 78, 185-205

Humphrey, O. S., Young, S. D., Bailey, E. H., Crout, N. M. J., Ander, E. L., \& Watts, M. J. (2018). Iodine soil dynamics and methods of measurement: a review. Environmental Science Processes \& Impacts, 20, 288-310

Humphrey, O. S., Young, S. D., Crout, N. M. J., Bailey, E. H., Ander, E. L., \& Watts, M. J. (2020). Short-term iodine dynamics in soil solution. Environmental Science \& Technology, 54, 1443-14450

Jensen, H., Orth, B., Reiser, R., Bürge, D., Lehto, N. J., Almond, P., Gaw, S., Thomson, B., Lilburne, L., \& Robinson, B. (2019). Environmental parameters affecting the concentration of iodine in New Zealand pasture. Journal of Environmental Quality, 48, 1517-1523

Jeong, H., Kim, H., \& Jang, T. (2016). Irrigation water quality standards for indirect wastewater reuse in agriculture: a contribution toward sustainable wastewater reuse in South Korea. Water, 8, 169

Johnson, C.C. (2003). The geochemistry of iodine and its application to environmental strategies for reducing the risks from iodine deficiency disorders (IDD). British Geological Survey Commissioned Report, CR/03/057N.

Johnson, C. C., Fordyce, F. M., \& Rayman, M. P. (2010). Symposium on 'Geographical and geological influences on nutrition'Factors controlling the distribution of selenium in the environment and their impact on health and nutrition. Proceedings of the Nutrition Society, 69, 119-132

Johnson, C.C., Fordyce, F.M. \& Stewart, A.G. (2003). Environmental controls in Iodine Deficiency Disorders Project Summary Report. British Geological Survey Commissioned Report, CR/03/058N.

Johnson, C.C., Strutt, M.H., Hmeurras, M. \& Mounir, M. (2002). Iodine in the environment of the high Atlas Mountain, Morocco. British Geological Survey Comissioned Report, CR/02/196N.

Jones, G. D., Droz, B., Greve, P., Gottschalk, P., Poffet, D., McGrath, S. P., Seneviratne, S. I., Smith, P., \& Winkel, L. H. E. (2017). Selenium deficiency risk predicted to increase under future climate change. Proceeings of the National Academy of Sciences of the United Satates of Amrica, 114, 2848-2853

Kabata-Pendias, A., \& Mukherjee, A. B. (2007). Trace elements from soil to human. Springer.

Karim, A.B. (2018). Selenium and iodine status in the Kurdistan region of Iraq. PhD Thesis. University of Nottingham.

Kelly, F., \& Snedden, W. (1958). Prevalence and geographical distribution of endemic goitre. Bulletin of the World Health Organization, 18, 5

Kerry, R., Rawlins, B. G., Oliver, M. A., \& Lacinska, A. M. (2009). Problems with determining the particle size distribution of chalk soil and some of their implications. Geoderma, 152, 324-337

Keskinen, R., Ekholm, P., Yli-Halla, M., \& Hartikainen, H. (2009). Efficiency of different methods in extracting selenium from agricultural soils of Finland. Geoderma, 153, 87-93

Khattak, R. M., Khattak, M. N. K., Ittermann, T., \& Völzke, H. (2017). Factors affecting sustainable iodine deficiency elimination in Pakistan: A global perspective. Journal of Epidemiology, 27, 249-257

Köhler, F., Riebe, B., Scheinost, A. C., König, C., Hölzer, A., \& Walther, C. (2019). Sorption of iodine in soils: insight from selective sequential extractions and X-ray absorption spectroscopy. Environmental Science and Pollution Research, 26, 23850-23860

Koljonen, T. (1973). Selenium in certain metamorphic rocks. Bulletin of the geological society of Finland, 45, 107-117

Kulp, T. R., \& Pratt, L. M. (2004). Speciation and weathering of selenium in upper cretaceous chalk and shale from South Dakota and Wyoming, USA. Geochimica et Cosmochimica Acta, 68, 3687-3701

Låg, J., \& Steinnes, E. (1976). Regional distribution of halogens in Norwegian forest soils. Geoderma, 16, 317-325

Li, J., Qian, K., Yang, Y., \& Xie, X. (2017). Iodine speciation and its potential influence on iodine enrichment in groundwater from north China plain. Procedia Earth and Planetary Science, 17, 312-315

Li, J., Wang, Y., Xie, X., Zhang, L., \& Guo, W. (2013). Hydrogeochemistry of high iodine groundwater: a case study at the Datong Basin, northern China. Environmental Science: Processes \& Impacts, 15, 848-859 
Li, Z., Liang, D., Peng, Q., Cui, Z., Huang, J., \& Lin, Z. (2017). Interaction between selenium and soil organic matter and its impact on soil selenium bioavailability: A review. Geoderma, 295, 69-79

Ligowe, I. S., Young, S. D., Ander, E. L., Kabambe, V., Chilimba, A. D. C., Bailey, E. H., Lark, R. M., \& Nalivata, P. C. (2019). Agronomic biofortification of leafy vegetables grown in an oxisol, alfisol and vertisol with isotopically labelled selenium $\left({ }^{77} \mathrm{Se}\right)$. Geoderma, 361, 114106

Ligowe, I. S., Young, S. D., Ander, E. L., Kabambe, V., Chilimba, A. D. C., Bailey, E. H., Lark, R. M., \& Nalivata, P. C. (2020). Selenium biofortification of crops on a Malawi alfisol under conservation agriculture. Geoderma, 369, 114115

Lopes, G., Ávila, F. W., \& Guilherme, L. R. G. (2017). Selenium behavior in the soil environment and its implication for human health. Ciência e Agrotecnologia, 41, 605-615

Lyons, G. (2018). Biofortification of cereals with foliar selenium and iodine could reduce hypothyroidism. Frontiers in Plant Science, 9, 730

Magomedova, L. A., Zyrin, N. G., \& Salmanov, A. B. (1970). Iodine in soils and rocks of the mountains of Dagestan. Agrokhimiya, 1, 117-125 (In Russian).

Maity, S., Sandeep, P., Dusane, C. B., Chaudhary, D. K., Sahu, S. K., \& Pandit, G. G. (2017). Studies on distribution coefficient of iodine in soil samples across industrial area. Research Journal of Chemical and Environmental Sciences, 5, 73-78

Maksimovic, Z., Jovic, V., Djujic, I., \& Rsumovic, M. (1992). Selenium deficiency in Yugoslavia and possible effects on health. Environmental Geochemistry and Health, 14, 107-111

Malagoli, M., Schiavon, M., dall'Acqua, S. \& Pilon-Smits, E.A.H. (2015). Effects of selenium biofortification on crop nutritional quality. Frontiers in Plant Science, 6, 280.

Malik, M.A. \& Azam, M. (2009). Impact evaluation of existing irrigation and agronomic practices on irrigation efficiency and crop yields in northern areas of Pakistan. Pakistan Council of Research in Water Resources Publication No.139-2009.

Manousou, S., \& Stål, M., Eggertsen, R., Hoppe, M., Hulthén, L. \& Nyström, H.F., (2019). Correlations of water iodine concentration to earlier goitre frequency in Sweden-an iodine sufficient country with long-term iodination of table salt. Environmental Health and Preventive Medicine, 24, 73 .

Mathers, A. (2015). Modelling the fate of selenium added to soil to improve biofortification efficiency. $\mathrm{PhD}$ Thesis. University of Nottingham.

Matos, R. P., Lima, V. M. P., Windmöller, C. C., \& Nascentes, C. C. (2017). Correlation between the natural levels of selenium and soil physicochemical characteristics from the Jequitinhonha Valley (MG), Brazil. Journal of Geochemical Exploration, 172, 195-202

McGowan, W. (2000). Water processing: residential, commercial, light-industrial. (3rd ed.). Water Quality Association.

Medrano-Macías, J., Leija-Martínez, P., González-Morales, S., Juárez-Maldonado, A., \& Benavides-Mendoza, A. (2016). Use of iodine to biofortify and promote growth and stress tolerance in crops. Frontiers in Plant Science, 7, $1146-1146$

Mohiuddin, M., Irshad, M., Ping, A., Hussain, Z., \& Shahzad, M. (2019). Bioavailability of iodine to mint from soil applied with selected amendments. Environmental Pollutants and Bioavailability, 31, 138-144

Moran, J.E., Oktay, S.D. \& Santschi, P.H. (2002). Sources of iodine and iodine 129 in rivers. Water Resources Research, 38, 24-1-24-10.

Ponce De León, C. A., Denicola, K., Bayón, M. M., \& Caruso, J. A. (2003). Sequential extractions of selenium soils from Stewart lake: total selenium and speciation measurements with ICP-MS detection. Journal of Environmental Monitoring, 5, 435-440

Qian, K., Li, J., Xie, X., \& Wang, Y. (2017). Organic and inorganic colloids impacting total iodine behavior in groundwater from the Datong Basin, China. Science of the Total Environment, 601-602, 380-390

Qin, H.-b, Zhu, J.-m, \& Su, H. (2012). Selenium fractions in organic matter from Se-rich soils and weathered stone coal in selenosis areas of China. Chemosphere, 86, 626-633

Rahman, M. M., Erskine, W., Zaman, M. S., Thavarajah, P., Thavarajah, D., \& Siddique, K. H. M. (2013). Selenium biofortification in lentil (Lens culinaris Medikus subsp. culinaris): Farmers' field survey and genotype $\times$ environment effect. Food Research International, 54, 1596-1604

Ramkissoon, C. (2020). Selenium dynamics in cereal biofortification: optimising fertiliser strategies and assessing residual fate. $\mathrm{PhD}$ thesis, University of Nottingham.

Rayman, M. P. (2000). The importance of selenium to human health. The Lancet, 356, 233-241

Riaz, A., Abbas, A., Noor-ul-Huda., Mubeen, H., Ibrahim, N. \& Raza, S. (2018). Methods to Enhance Selenium in Wheat through Biofortification: A Review. Journal of Biotechnology \& Biomaterials, 8, 1000282

Rowell, D. L. (1994). Soil science methods and applications. Longman Scientific and Technical.

Rucklidge, J., Kilius, L., \& Fuge, R. (1994). ${ }^{129}$ I in moss downwind from the Sellafield nuclear fuel reprocessing plant. Nuclear Instruments and Methods in Physics Research Section B: Beam Interactions with Materials and Atoms, 92, 417-420

Saha, S., Fayiga, A., \& Sonon, L. (2017). Selenium in the SoilPlant Environment: A Review. International Journal of Applied Agricultural Sciences, 3, 1-18

Sanders, H. K. (2018). Interactions between anionic radionuclides (129I, 79Se and 99Tc) and soil geocolloids. PhD thesis. University of Nottingham.

Schilling, K., Johnson, T. M., \& Mason, P. R. D. (2014). A sequential extraction technique for mass-balanced stable selenium isotope analysis of soil samples. Chemical Geology, 381, 125-130

Schilling, K., Johnson, T. M., \& Wilcke, W. (2011). Selenium partitioning and stable isotope ratios in urban topsoils. Soil Science Society of America Journal, 75, 1354-1364

Schmitz, K., \& Aumann, D. C. (1994). Why are the soil-topasture transfer factors, as determined by field measurements, for ${ }^{127} \mathrm{I}$ lower than for ${ }^{129} \mathrm{I}$ ? Journal of Environmental Radioactivity, 24, 91-100 
Séby, F., Gautier, M. P., Lespés, G., \& Astruc, M. (1997). Selenium speciation in soils after alkaline extraction. Science of The Total Environment, 207, 81-90

Shamberger, R. J. (1981). Selenium in the environment. Science of the Total Environment, 17, 59-74

Shetaya, W. H., Young, S. D., Watts, M. J., Ander, E. L., \& Bailey, E. H. (2012). Iodine dynamics in soils. Geochimica et Cosmochimica Acta, 77, 457-473

Smith, J. D., \& Butler, E. C. V. (1979). Speciation of dissolved iodine in estuarine waters. Nature, 277, 468

Söderlund, M., Lusa, M., Lehto, J., Hakanen, M., Vaaramaa, K., \& Lahdenperä, A.-M. (2011). Sorption of iodine, chlorine, technetium and cesium in soil. Working Report, 4, 130

Söderlund, M., Virkanen, J., Aromaa, H., Gracheva, N., \& Lehto, J. (2017). Sorption and speciation of iodine in boreal forest soil. Journal of Radioanalytical and Nuclear Chemistry, 311, 549-564

Stewart, A. (1990). For debate: drifting continents and endemic goitre in northern Pakistan. British Medical Journal, 300, $1507-1512$

Stroud, J. L., Broadley, M. R., Foot, I., Fairweather-Tait, S. J., Hart, D. J., Hurst, R., Knott, P., Mowat, H., Norman, K., Scott, P., Tucker, M., White, P. J., McGrath, S. P., \& Zhao, F. J. (2010). Soil factors affecting selenium concentration in wheat grain and the fate and speciation of Se fertilisers applied to soil. Plant Science, 332, 19-30

Stroud, J. L., Mcgrath, S. P., \& Zhao, F. J. (2012). Selenium speciation in soil extracts using LC-ICP-MS. International Journal of Environmental Analytical Chemistry, 92, 222-236

Sun, D., Codling, K., Chang, S., Zhang, S., Shen, H., Su, X., Chen, Z., Scherpbier, R. W., \& Yan, J. (2017). Eliminating iodine deficiency in China: achievements, challenges and global implications. Nutrients, 9, 361

Supriatin, S., Weng, L., \& Comans, R. N. J. (2016). Seleniumrich dissolved organic matter determines selenium uptake in wheat grown on Low-selenium arable land soils. Plant and Soil, 408, 73-94

Takaku, Y., Shimamura, T., Masuda, K., \& Igarashi, Y. (1995). Iodine Determination in natural and tap water using inductively coupled plasma mass spectrometry. Analytical Sciences, 11, 823-827

Tan, J. A., Zhu, W., Wang, W., Li, R., Hou, S., Wang, D., \& Yang, L. (2002). Selenium in soil and endemic diseases in China. Science of The Total Environment, 284, 227-235

Tolu, J., Le Hécho, I., Bueno, M., Thiry, Y., \& Potin-Gautier, M. (2011). Selenium speciation analysis at trace level in soils. Analytica Chimica Acta, 684, 126-133

United States Geological Survey (USGS). (2021). Hardness of water. https://www.usgs.gov/special-topic/water-scienceschool/science/hardness-water?qt-science_center_ objects=0\#qt-science_center_objects (Accessed 25 January 2021).

Vanderpas, J. B., Contempre, B., Duale, N. L., Goossens, W., Bebe, N., Thorpe, R., Ntambue, K., Dumont, J., Thilly, C. H., \& Diplock, A. T. (1990). Iodine and selenium deficiency associated with cretinism in northern Zaire. The American Journal of Clinical Nutrition, 52, 1087-1093

Wang, C., Li, S., Wang, H., \& Fu, J. (2016). Selenium minerals and the recovery of selenium from copper refinery anode slimes. The Journal of the South African Institute of Mining and Metallurgy, 116, 593-600

Wang, D., Alfthan, G., Aro, A., Lahermo, P., \& Väänänen, P. (1994). The impact of selenium fertilisation on the distribution of selenium in rivers in Finland. Agriculture, Ecosystems \& Environment, 50, 133-149

Wang, G., Qafoku, N. P., Szecsody, J. E., Strickland, C. E., Brown, C. F., \& Freedman, V. L. (2019). Time-dependent iodate and iodide adsorption to Fe oxides. ACS Earth and Space Chemistry, 3, 2415-2420

Wang, S., Liang, D., Wang, D., Wei, W., Fu, D., \& Lin, Z. (2012). Selenium fractionation and speciation in agriculture soils and accumulation in corn (zea mays L.) under field conditions in Shaanxi Province. China. Science of The Total Environment, 427-428, 159-164

Watts, M. J., \& Mitchell, C. J. (2009). A pilot study on iodine in soils of Greater Kabul and Nangarhar provinces of Afghanistan. Environmental Geochemistry and Health, 31, 503-509

Watts, M. J., Joy, E. J. M., Young, S. D., Broadley, M. R., Chilimba, A. D. C., Gibson, R. S., Siyame, E. W. P., Kalimbira, A. A., Chilima, B., \& Ander, E. L. (2015). Iodine source apportionment in the Malawian diet. Scientific Reports, 5, 15251

Watts, M. J., Middleton, D. R. S., Marriott, A. L., Humphrey, O. S., Hamilton, E. H., Gardner, A., Smith, M., McCormack, V. A., Menya, D., Munishi, M. O., Mmbaga, B. T., \& Osano, O. (2019). Source apportionment of micronutrients in the diets of Kilimanjaro, Tanzania and Counties of Western Kenya. Scientific Reports, 9, 14447

Watts, M. J., \& O'reilly, J., Maricelli, A., Coleman, A., Ander, E.L. \& Ward, N.I. . (2010). A snapshot of environmental iodine and selenium in La Pampa and San Juan provinces of Argentina. Journal of Geochemical Exploration, 107, 87-93

White, P. J. (2016). Selenium accumulation by plants. Annals of Botany, 117, 217-235

Whitehead, D. (1973). Uptake and distribution of iodine in grass and clover plants grown in solution culture. Journal of the Science of Food and Agriculture, 24, 43-50

Whitehead, D. C. (1984). The distribution and transformations of iodine in the environment. Environment International, 10, 321-339

WHO (World Health Organisation). (2011b). Hardness in Drinking-water; Background document for development of WHO guidelines for drinking-water, WHO/HSE/WSH/ . https://doi.org/10.01/10/Rev/1.

Winkel, L. H. E., Johnson, C. A., Lenz, M., Grundl, T., Leupin, O. X., Amini, M., \& Charlet, L. (2012). Environmental selenium research: from microscopic processes to global understanding. Environmental Science \& Technology, 46, 571-579

Woch, W., \& Hawrylak-Nowak, B. (2019). Selected antioxidant properties of alfalfa, radish, and white mustard sprouts biofortified with selenium. Acta Agrobotanica, 72, 1-11

Wu, L., Yu, J.-C., Kang, W.-M., \& Ma, Z.-Q. (2013). Iodine nutrition and thyroid diseases. Zhongguо yi хие ke хие yиan xue bao. Acta Academiae Medicinae Sinicae, 35, 363-368

Wuilloud, R., \& Berton, P. (2014). Selenium speciation in the environment. In S. Bakirdere (Ed.), Speciation Studies in 
Soil, Sediment and Environmental Samples. (pp. 263-305). CRC Press.

Xing, K., Zhou, S., Wu, X., Zhu, Y., Kong, J., Shao, T., \& Tao, X. (2015). Concentrations and characteristics of selenium in soil samples from Dashan Region, a selenium-enriched area in China AU - Xing, Kun. Soil Science and Plant Nutrition, 61, 889-897

Yadav, S. K., Singh, I., Singh, D., \& Han, S.-D. (2005). Selenium status in soils of northern districts of India. Journal of Environmental Management, 75, 129-132

Yamada, H., Kiriyama, T., Onagawa, Y., Hisamori, I., Miyazaki, C., \& Yonebayashi, K. (1999). Speciation of iodine in soils. Soil Science and Plant Nutrition, 45, $563-568$

Yamasaki, S.-I., Takeda, A., Watanabe, T., Tagami, K., Uchida, S., Takata, H., Maejima, Y., Kihou, N., \& Tsuchiya, N. (2015). Bromine and iodine in Japanese soils determined with polarizing energy dispersive X-ray fluorescence spectrometry. Soil Science and Plant Nutrition, 61, 751-760

Yang, R., Liu, Y., \& Zhou, Z. (2017). Selenium and Selenoproteins, from Structure, Function to Food Resource and
Nutrition. Food Science and Technology Research, 23, 363-373

Zaman, M., Shahid, S.A. \& Heng, L. (2018). Guideline for salinity assessment, mitigation and adaptation using nuclear and related techniques. Springer Nature.

Zhang, Y., \& Moore, J. N. (1996). Selenium fractionation and speciation in a wetland system. Environmental Science \& Technology, 30, 2613-2619

Zia, M. H., Watts, M. J., Gardner, A., \& Chenery, S. R. (2014). Iodine status of soils, grain crops, and irrigation waters in Pakistan. Environmental Earth Sciences, 73, 7995-8008

Zia, M. H., Watts, M. J., Niaz, A., Middleton, D. R. S., \& Kim, A. W. (2017). Health risk assessment of potentially harmful elements and dietary minerals from vegetables irrigated with untreated wastewater, Pakistan. Environmental Geochemistry and Health, 39, 707-728

Publisher's Note Springer Nature remains neutral with regard to jurisdictional claims in published maps and institutional affiliations. 